\title{
Chemical and physical transformations of organic aerosol from the photo-oxidation of open biomass burning emissions in an environmental chamber
}

\author{
C. J. Hennigan ${ }^{1}$, M. A. Miracolo ${ }^{1}$, G. J. Engelhart ${ }^{1}$, A. A. May ${ }^{1}$, A. A. Presto ${ }^{1}$, T. Lee ${ }^{2}$, A. P. Sullivan ${ }^{2}$, \\ G. R. McMeeking ${ }^{2,3}$, H. Coe ${ }^{3}$, C. E. Wold ${ }^{4}$, W.-M. Hao ${ }^{4}$, J. B. Gilman ${ }^{5,6}$, W. C. Kuster ${ }^{5,6}$, J. de Gouw ${ }^{5,6}$, \\ B. A. Schichtel ${ }^{7}$, J. L. Collett Jr. ${ }^{2}$, S. M. Kreidenweis ${ }^{2}$, and A. L. Robinson ${ }^{1}$ \\ ${ }^{1}$ Center for Atmospheric Particle Studies, Carnegie Mellon University, USA \\ ${ }^{2}$ Department of Atmospheric Science, Colorado State University, USA \\ ${ }^{3}$ Centre for Atmospheric Science, University of Manchester, UK \\ ${ }^{4}$ Missoula Fire Sciences Laboratory, US Forest Service, USA \\ ${ }^{5}$ Earth System Research Laboratory, National Oceanic and Atmospheric Administration, USA \\ ${ }^{6}$ Cooperative Institute for Research in Environmental Sciences, University of Colorado at Boulder, USA \\ ${ }^{7}$ National Park Service/CIRA, Colorado State University, USA
}

Received: 12 April 2011 - Published in Atmos. Chem. Phys. Discuss.: 18 April 2011

Revised: 18 July 2011 - Accepted: 20 July 2011 - Published: 1 August 2011

\begin{abstract}
Smog chamber experiments were conducted to investigate the chemical and physical transformations of organic aerosol (OA) during photo-oxidation of open biomass burning emissions. The experiments were carried out at the US Forest Service Fire Science Laboratory as part of the third Fire Lab at Missoula Experiment (FLAME III). We investigated emissions from 12 different fuels commonly burned in North American wildfires. The experiments feature atmospheric and plume aerosol and oxidant concentrations; aging times ranged from 3 to $4.5 \mathrm{~h}$. OA production, expressed as a mass enhancement ratio (ratio of OA to primary OA (POA) mass), was highly variable. OA mass enhancement ratios ranged from 2.9 in experiments where secondary OA (SOA) production nearly tripled the POA concentration to 0.7 in experiments where photo-oxidation resulted in a $30 \%$ loss of the OA mass. The campaign-average OA mass enhancement ratio was $1.7 \pm 0.7$ (mean $\pm 1 \sigma$ ); therefore, on average, there was substantial SOA production. In every experiment, the OA was chemically transformed. Even in experiments with net loss of OA mass, the OA became increasingly oxygenated and less volatile with aging, indicating that photo-oxidation transformed the POA emissions. Levoglucosan concentra-
\end{abstract}

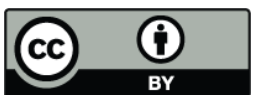

Correspondence to: A. L. Robinson (alr@andrew.cmu.edu) tions were also substantially reduced with photo-oxidation. The transformations of POA were extensive; using levoglucosan as a tracer for POA, unreacted POA only contributed $17 \%$ of the campaign-average OA mass after $3.5 \mathrm{~h}$ of exposure to typical atmospheric hydroxyl radical $(\mathrm{OH})$ levels. Heterogeneous reactions with $\mathrm{OH}$ could account for less than half of this transformation, implying that the coupled gasparticle partitioning and reaction of semi-volatile vapors is an important and potentially dominant mechanism for POA processing. Overall, the results illustrate that biomass burning emissions are subject to extensive chemical processing in the atmosphere, and the timescale for these transformations is rapid.

\section{Introduction}

Biomass combustion is a significant source of particle- and gas-phase pollutants and thus exerts important impacts on air quality and climate (Crutzen and Andreae, 1990). On a global scale biomass burning is responsible for almost $90 \%$ of primary organic aerosol (POA) emissions (Bond et al., 2004). Biomass burning also emits substantial amounts of organic gases and vapors, some of which react in the atmosphere to form secondary organic aerosol (SOA). However, estimates of the contribution of biomass burning emissions to

Published by Copernicus Publications on behalf of the European Geosciences Union. 


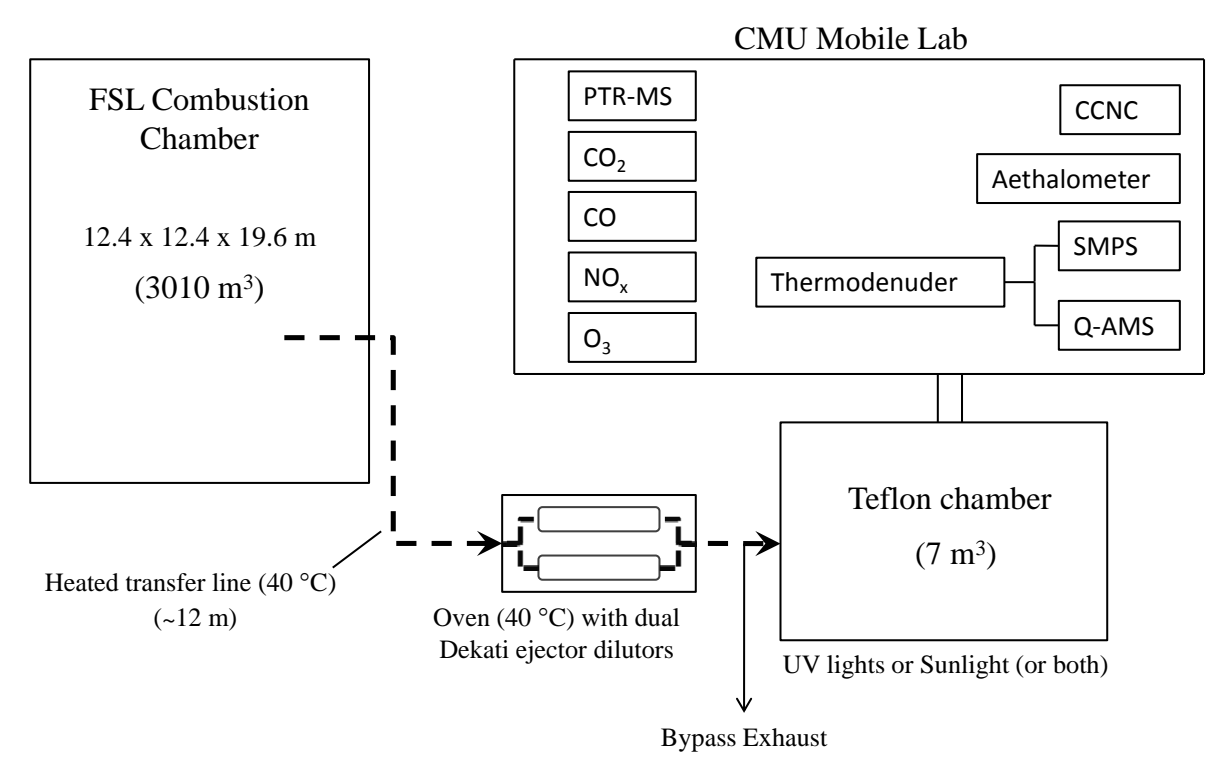

Fig. 1. Schematic of experimental setup used for the photo-oxidation experiments (not drawn to scale).

SOA are highly uncertain (Hallquist et al., 2009). The current understanding of SOA formation is incomplete (e.g., de Gouw et al., 2005; Heald et al., 2005) and models underpredict SOA concentrations in aging fire plumes (Alvarado and Prinn, 2009; Grieshop et al., 2009b).

Field studies report widely varying amounts of SOA formation from biomass burning emissions (de Gouw and Jimenez, 2009). Some studies report substantial SOA formation; for example, Yokelson et al. (2009) observed a doubling of the organic aerosol (OA) mass concentration relative to $\mathrm{CO}$ in a Yucatan fire plume after $\sim 1.5 \mathrm{~h}$ of aging. Lee et al. (2008) also report significant SOA formation from aged prescribed burn emissions during an air quality event in Atlanta. OA concentrations increased by more than a factor of two (Grieshop et al., 2009a, b) and a factor of four (Heringa et al., 2011) in separate studies investigating the photo-oxidation of residential wood burning emissions in smog chambers.

Other field studies report more modest SOA production from fire emissions. For example, DeCarlo et al. (2010) report OA mass enhancements of $\sim 30-40 \%$ after fire emissions had aged for approximately one day over Mexico. Similarly, Reid et al. (1998) observed OA mass enhancements of $20-40 \%$ in biomass burning emissions that had aged for days over Brazil. In African savannah fire emissions (Capes et al., 2008) and Canadian boreal fire plumes (Hecobian et al., 2011; Cubison et al., 2011), OA mass concentrations did not increase relative to $\mathrm{CO}$ as the emissions aged despite observations being made very close to the source. However, all of these studies did report substantial changes in the chemical and physical properties of the OA, suggesting a dynamic aging process for these systems. Both the variable nature of biomass emissions (e.g., Andreae and Merlet, 2001) and the large uncertainties in SOA formation demonstrate the need to empirically characterize SOA from biomass burning.

Environmental chambers provide an opportunity to investigate the OA chemistry under well characterized aging conditions, pollutant concentrations, fuel type and combustion conditions. Further, in the laboratory, smoke can be aged in the absence of other emissions, such as dust or anthropogenic pollution. Laboratory data can then be used to develop predictions for the field that can be evaluated through direct measurements and models.

As part of the third Fire Lab at Missoula Experiment (FLAME III) study, we conducted a series of smog chamber experiments to investigate the effects of photo-oxidation on emissions from open biomass combustion. We investigated 12 different vegetation types commonly burned in North American wildfires (Table 1). The specific objectives of this paper include quantifying net SOA production and characterizing chemical transformations of POA.

\section{Materials and methods}

\subsection{Methods}

The FLAME III study was conducted at the US Forest Service Fire Science Laboratory (FSL) in Missoula, MT during September-October 2009. To investigate the effects of photo-oxidation, primary emissions were sampled into an environmental or smog chamber after conducting a "chamber burn" in the FSL's main combustion chamber, a $12.4 \mathrm{~m} \times 12.4 \mathrm{~m} \times 19.6 \mathrm{~m}$ room (Fig. 1). The FSL facility is described in detail elsewhere (Yokelson et al., 1996; Christian et al., 2003; McMeeking et al., 2009). FLAME III investigated fuels representing different regions in North America 
Table 1. Primary emission factors measured in the combustion chamber.

\begin{tabular}{|c|c|c|c|c|c|}
\hline $\begin{array}{c}\text { Burn } \\
\text { number }^{\mathrm{a}}\end{array}$ & Burn date & Fuel & Name & Material & $\mathrm{CO}_{2}^{\mathrm{b}}$ \\
\hline 37 & 19 Sep 2009 & Lodgepole Pine & Pinus contorta & branches, leaves & 1551 \\
\hline 40 & 21 Sep 2009 & Ponderosa Pine & Pinus ponderosa & branches, leaves & \\
\hline 42 & 22 Sep 2009 & Wire Grass & Aristida beyrichiana & Grass & 1784 \\
\hline 43 & 23 Sep 2009 & Saw Grass & Cladium mariscus & leaves (grass-like) & 1765 \\
\hline 49 & 26 Sep 2009 & Sage & Artemisia tridentata & branches, leaves & 1714 \\
\hline 51 & 28 Sep 2009 & Alaskan Duff & Hylocomium splendens, Sphagnum spp. & decayed vegetation matter & 1501 \\
\hline 53 & 29 Sep 2009 & Sage & Artemisia tridentata & branches, leaves & 1733 \\
\hline 55 & 30 Sep 2009 & White Spruce & Picea glauca & branches, leaves & 1704 \\
\hline 57 & 1 Oct 2009 & Ponderosa Pine & Pinus ponderosa & branches, leaves & 1603 \\
\hline 66 & 7 Oct 2009 & Black Spruce & Picea mariana & branches, leaves & 1847 \\
\hline 67 & 8 Oct 2009 & Wire Grass & Aristida beyrichiana & grass & 1794 \\
\hline
\end{tabular}

Table 1. Continued.

\begin{tabular}{ccccccc}
\hline Burn number $^{\mathrm{a}}$ & Burn date & $\mathrm{CO}^{*}$ & $\mathrm{NO}_{\mathrm{x}}^{\mathrm{b}}$ & $\mathrm{MCE}$ & $\mathrm{OC}^{\mathrm{c}}$ & $\mathrm{EC}^{\mathrm{c}}$ \\
\hline 37 & 19 Sep 2009 & 113.0 & 7.6 & 0.90 & 32.6 & 0.54 \\
38 & 20 Sep 2009 & 82.9 & 3.0 & 0.93 & 11.4 & 0.41 \\
40 & 21 Sep 2009 & & & & & \\
42 & 22 Sep 2009 & 38.1 & 3.1 & 0.97 & 1.51 & 0.39 \\
43 & 23 Sep 2009 & 49.4 & 3.9 & 0.96 & 1.57 & 0.69 \\
45 & 24 Sep 2009 & 62.1 & 3.1 & 0.95 & 1.04 & 0.25 \\
47 & 25 Sep 2009 & 59.8 & 2.7 & 0.95 & 8.72 & 0.41 \\
49 & 26 Sep 2009 & 89.4 & 4.6 & 0.92 & 2.12 & 1.12 \\
51 & 28 Sep 2009 & 89.2 & 1.7 & 0.91 & 4.96 & \\
53 & 29 Sep 2009 & 88.2 & 5.8 & 0.93 & 0.78 & 0.66 \\
55 & 30 Sep 2009 & 69.3 & 2.3 & 0.94 & 6.55 & 1.01 \\
57 & 1 Oct 2009 & 96.9 & 1.8 & 0.91 & 27.7 & 0.25 \\
59 & 2 Oct 2009 & 71.1 & 3.3 & 0.94 & 0.52 & 0.86 \\
61 & 4 Oct 2009 & 128.4 & 3.0 & 0.89 & 28.1 & 0.37 \\
63 & 5 Oct 2009 & 54.7 & 2.8 & 0.96 & 1.44 & 0.29 \\
65 & 6 Oct 2009 & 81.4 & 3.9 & 0.93 & 10.0 & 0.35 \\
66 & 7 Oct 2009 & 60.2 & 3.5 & 0.95 & 2.79 & 0.25 \\
67 & 8 Oct 2009 & 38.9 & 3.6 & 0.97 & 1.62 & 0.37 \\
\hline
\end{tabular}

${ }^{a}$ Numbering convention used during the FLAME-III study; ${ }^{b}$ emission factors in units of $\mathrm{g} \mathrm{kg}^{-1}$ dry fuel; ${ }^{\mathrm{c}}$ emission factors in units of $\mathrm{g}-\mathrm{C} \mathrm{kg}^{-1}$ dry fuel

commonly impacted by prescribed burning and wildfires (Table 1), including the Southeast (e.g., gallberry and pocosin), southern California (e.g., sagebrush and chamise) and forest regions of the western United States and Canada (e.g., ponderosa pine, lodgepole pine, and black spruce).
During a chamber burn, a small mass $(0.3-1.0 \mathrm{~kg})$ of fuel was placed on a ceramic plate atop a scale used to quantify the mass of fuel consumed during combustion. The fuel was ignited using electric heating coils that were pre-conditioned with a small amount of ethanol $(\sim 5 \mathrm{ml})$. The fuel bed was allowed to burn to completion, filling the FSL $3000 \mathrm{~m}^{3} \mathrm{com}-$ bustion chamber with smoke from the entire burn event, including the flaming and smoldering phases. The FSL combustion chamber typically became well-mixed within $20 \mathrm{~min}$ after the burn was completed, as indicated by a suite of gas and aerosol measurements.

The schematic in Fig. 1 shows the experimental set up for the photo-oxidation experiments, which were performed in a $7.0 \mathrm{~m}^{3}$ Teflon smog chamber located outdoors, immediately adjacent to the western wall of the FSL burn chamber facility. Instrumentation for chamber experiments was housed in the Carnegie Mellon University (CMU) mobile air quality laboratory, which was parked adjacent to the smog chamber.

Two ejector dilutors (Dekati, Helsinki, Finland) and a heated, stainless steel transfer line were used to fill the smog chamber with smoke from the FSL combustion chamber. This inlet system pulled smoke from the FSL combustion chamber at a total flow rate of $151 \mathrm{~min}^{-1}$. The inlet to the transfer line inside the FSL combustion chamber was $\sim 2 \mathrm{~m}$ from the wall and $\sim 2 \mathrm{~m}$ off the ground to minimize wall or boundary effects. The transfer line was constructed of stainless steel tubing ( 0.42 inch ID) with a total length of approximately $12 \mathrm{~m}$. The transfer line and ejector dilutors were electrically heated to $40^{\circ} \mathrm{C}$ to reduce losses of semi-volatile 
components. The ejector dilutors were operated on conditioned (dried, HEPA- and activated-carbon filtered) air that had been heated to $40^{\circ} \mathrm{C}$. Prior to filling the smog chamber, the transfer line system was flushed with heated conditioned air for $1.5 \mathrm{~h}$ and then flushed with smoke from the FSL burn chamber for $30 \mathrm{~min}$, venting the smoke through a bypass exhaust immediately upstream of the smog chamber. This was done to condition the transfer line, which should reduce losses of semi-volatile organic vapors. Particle losses in the transfer line system were characterized in separate experiments using dried atomized sodium chloride aerosol. The transmission efficiency was, on average, 0.94 across a particle electrical mobility diameter size range of $50-400 \mathrm{~nm}$. No corrections were applied to account for losses in the transfer line.

Before each experiment, the portable smog chamber was flushed for at least $12 \mathrm{~h}$ with conditioned air and then partially evacuated prior to smoke injection. After injection, the final dilution ratio of the smoke inside the smog chamber was $\sim 25: 1$ (relative to the FSL combustion chamber). Initial aerosol concentrations inside the smog chamber after filling ranged from $13-85 \mu \mathrm{g} \mathrm{m}^{-3}$, which are representative of ambient to plume-like conditions. A blank experiment was performed in which the smog chamber was flushed with clean, dry air for $12 \mathrm{~h}$, and then exposed to sunlight and UV lights to ensure that evolution of the OA in experiments was not affected by chamber or background conditions.

After filling the smog chamber, primary gas and particle concentrations were characterized for $75 \mathrm{~min}$. Photooxidation was then initiated by turning on UV lights (GE model 10526 blacklights) and by removing the tarp to expose the smog chamber to natural sunlight, weather permitting (Table 2). The photo-chemical aging lasted for $3-4.5 \mathrm{~h}$ during which the temperature in the smog chamber increased $11.5 \pm 3.4^{\circ} \mathrm{C}$ (average $\pm 1 \sigma$; see discussion in Sect. 3.2). Relative humidity (RH) inside the smog chamber was also variable, but was consistently low relative to ambient conditions. The maximum RH observed in each experiment was $30.0 \pm 6.1 \%$ (mean $\pm 1 \sigma$ ) while the average RH observed across all of the experiments was $19.2 \%$.

In 10 experiments (Table 2), nitrous acid (HONO) was added to the smog chamber following the method of $\mathrm{Ng}$ et al. (2007) before adding smoke from the FSL burn chamber. The UV light photolyzed HONO to enhance hydroxyl radical $(\mathrm{OH})$ levels (Table 2) and increase overall oxidant exposures. The addition of $\mathrm{HONO}$ also shifted the VOC: $\mathrm{NO}_{\mathrm{x}}$ regime from low $\mathrm{NO}_{\mathrm{x}}$ (experiments without $\mathrm{HONO}$ addition) to high $\mathrm{NO}_{\mathrm{x}}$ (Table 2).

A suite of instrumentation located in the CMU Mobile Air Quality Lab (Presto et al., 2011; Miracolo et al., 2011) was used to monitor gas and particle species inside the smog chamber. An Aerodyne Quadrupole Aerosol Mass Spectrometer (Q-AMS) was used to measure non-refractory aerosol mass, including OA as well as inorganic species sulfate, nitrate, chloride, potassium, and ammonium. Based on comparisons with SMPS measurements, the collection efficiency in the Q-AMS was taken to be 1, in agreement with another AMS laboratory investigation of biomass burning aerosol (Heringa et al., 2011). Q-AMS data at $\mathrm{m} / \mathrm{z}, 44$ were corrected for the measured $\mathrm{CO}_{2}$ concentrations. A scanning mobility particle sizer (SMPS, TSI model 3080) and condensation particle counter (CPC, TSI model 3772) measured aerosol number and volume distributions for particles in the size range 10.6-498 nm. Black carbon (BC) concentrations were measured with the $880 \mathrm{~nm}$ channel of a 7-channel Aethalometer (Magee Scientific model AE-31) corrected for aerosol loadings according to the method of Kirchstetter and Novakov (2007).

A thermodenuder based on the design of Huffman et al. (2009) was operated upstream of the SMPS and Q-AMS to investigate aerosol volatility. These instruments alternately sampled between a heated "through thermodenuder" and an ambient temperature "bypass" line. During the primary characterization period, the TD was run at temperatures of 40,80 , and $120^{\circ} \mathrm{C}$. The aerosol was sampled through the TD for $15 \mathrm{~min}$ at each temperature to quantify the extent of evaporation at two residence times $(7 \mathrm{~s}$ and $19 \mathrm{~s}$ centerline at $25^{\circ} \mathrm{C}$ ). During the first two hours of photo-oxidation, the TD was held constant at $80^{\circ} \mathrm{C}$ while the SMPS and Q-AMS measurements cycled between bypass and TD sampling (30 min per cycle). Finally, after $\sim 2.5 \mathrm{~h}$ of photo-oxidation, the primary TD program was repeated to investigate the volatility of the aged aerosol at 40,80 , and $120^{\circ} \mathrm{C}$.

For $15 \mathrm{~min}$ out of every hour, an Aerodyne HighResolution Time-of-Flight Aerosol Mass Spectrometer (HRAMS) operated by Colorado State University sampled from the smog chamber. The HR-AMS was located in the FSL burn chamber control room.

The concentrations of select VOCs inside the smog chamber were measured with a Proton Transfer Reaction-Mass Spectrometer (PTR-MS, Ionicon, Innsbruck, Austria). The PTR-MS was equipped with a quadrupole mass analyzer that achieved unit mass resolution, and hence was unable to resolve isobaric species such as $m-, o-$, and $p$-xylene. Along with ethylbenzene, these compounds were collectively quantified as "C-8 aromatics". The measured decay of benzene, toluene, and C-8 aromatic concentrations were used to infer $\mathrm{OH}$ levels (see supplemental material of Hennigan et al., 2010). Additional gas-phase measurements included carbon dioxide $\left(\mathrm{CO}_{2}\right.$, Licor Biosciences model LI$820)$, carbon monoxide ( $\mathrm{CO}$, API model 300$)$, ozone $\left(\mathrm{O}_{3}\right.$, API model $400 \mathrm{~A})$, and oxides of nitrogen $\left(\mathrm{NO}_{\mathrm{x}}\right.$, Teledyne model 200EU). Gas-phase instruments, including the PTRMS, were calibrated daily during the study. The PTR-MS was calibrated by directly measuring a custom blend of gases in $\mathrm{N}_{2}$ (Scott-Marrin, Inc., Riverside, California). The instrument was not calibrated for formic acid (included in Fig. 2), but instead, the average calibration response of two other light oxygenated compounds (methanol and acetaldehyde) was used to estimate the formic acid response. Gas-phase 
Table 2. Data from aging experiments. Blank entries indicates data not available.

\begin{tabular}{ccccc}
\hline Burn number $^{\mathrm{a}}$ & Fuel & Smog chamber POA $^{\mathrm{b}}$ & Smog chamber BC $^{\mathrm{b}}$ & VOC:NO $_{\mathrm{x}}^{\mathrm{c}}$ \\
\hline 37 & Lodgepole Pine & 36 & 1.7 & 44.5 \\
38 & Lodgepole Pine & 34 & 2.3 & 94.4 \\
40 & Ponderosa Pine & 58 & 1.5 & - \\
42 & Wire Grass & 9.3 & 7.1 & - \\
43 & Saw Grass & 6.6 & 10.1 & 19.1 \\
45 & Turkey Oak & 8.2 & 6.4 & 26.6 \\
47 & Gallberry & 35 & 4.2 & 39.1 \\
49 & Sage & 5.4 & 8.3 & 26.4 \\
51 & Alaskan Duff & 16 & - & 2.5 \\
53 & Sage & 5.3 & 9.5 & 0.22 \\
55 & White Spruce & 21 & 11.0 & 0.82 \\
57 & Ponderosa Pine & 71 & 1.8 & 1.41 \\
59 & Chamise & 5.9 & 16.7 & 0.29 \\
61 & Lodgepole Pine & 53 & 1.2 & 0.76 \\
63 & Pocosin & 16 & 10.0 & 0.19 \\
65 & Gallberry & 79 & 7.0 & 0.40 \\
66 & Black Spruce & 31 & 4.7 & 0.10 \\
67 & Wire Grass & 23 & 6.1 & 0.05 \\
\hline
\end{tabular}

Table 2. Continued.

\begin{tabular}{ccccc}
\hline Burn number $^{\mathrm{a}}$ & HONO added? & UV source & Total OH exposure $^{\mathrm{d}}$ & End of experiment OA mass enhancement ratio $^{\mathrm{e}}$ \\
\hline 37 & $\mathrm{~N}$ & Sunlight & $1.56 \times 10^{10}$ & $1.5 \pm 0.2$ \\
38 & $\mathrm{~N}$ & UV lights & $1.40 \times 10^{10}$ & $2.3 \pm 0.7$ \\
40 & $\mathrm{~N}$ & Both & $2.71 \times 10^{10}$ & $0.9 \pm 0.1$ \\
42 & $\mathrm{~N}$ & Both & $3.50 \times 10^{10}$ & $2.6 \pm 0.3$ \\
43 & $\mathrm{~N}$ & Both & $3.10 \times 10^{10}$ & $2.6 \pm 0.3$ \\
45 & $\mathrm{~N}$ & Both & $2.09 \times 10^{10}$ & $1.8 \pm 0.3$ \\
47 & $\mathrm{~N}$ & Both & $6.12 \times 10^{10}$ & $2.0 \pm 0.5$ \\
49 & $\mathrm{~N}$ & Both & $1.84 \times 10^{10}$ & $1.3 \pm 0.1$ \\
51 & $\mathrm{Y}$ & Both & - & $1.2 \pm 0.1$ \\
53 & $\mathrm{Y}$ & UV lights & - & $1.4 \pm 0.1$ \\
55 & $\mathrm{Y}$ & UV lights & $6.59 \times 10^{10}$ & $0.9 \pm 0.1$ \\
57 & $\mathrm{Y}$ & UV lights & $7.99 \times 10^{10}$ & $1.9 \pm 0.2$ \\
59 & $\mathrm{Y}$ & UV lights & $4.95 \times 10^{10}$ & $1.4 \pm 0.2$ \\
61 & $\mathrm{Y}$ & UV lights & $7.89 \times 10^{10}$ & $2.8 \pm 0.4$ \\
63 & $\mathrm{Y}$ & Both & $8.22 \times 10^{10}$ & $0.7 \pm 0.1$ \\
65 & $\mathrm{Y}$ & Both & $4.94 \times 10^{10}$ & $2.9 \pm 1.0$ \\
66 & $\mathrm{Y}$ & UV lights & $2.63 \times 10^{10}$ & $1.4 \pm 0.1$ \\
67 & $\mathrm{Y}$ & Both & $3.06 \times 10^{10}$ & \\
\hline
\end{tabular}

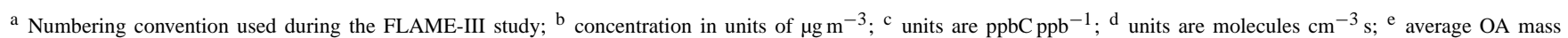
enhancement ratio given by $\omega=1$ and BC ratio methods (Sect. 2.2), with uncertainty representing measurement error and agreement between the two wall-loss estimates.

measurements were also made inside the FSL combustion chamber to characterize primary emission factors for each of the burns.

Teflon membrane filter samples $(25 \mathrm{~mm}$, Pall Corporation, P5PQ025) were collected from both the FSL combustion chamber and the CMU smog chamber to characterize the chemical composition of primary and aged aerosol using offline techniques. Filter samples were taken from the smog chamber after approximately $0.9,2.1$, and $3.3 \mathrm{~h}$ of photo-oxidation. The filters were extracted in deionized water and the extracts analyzed for cations and anions by ion chromatography (IC) with conductivity detection, and for 
Pocosin (10/5/09):
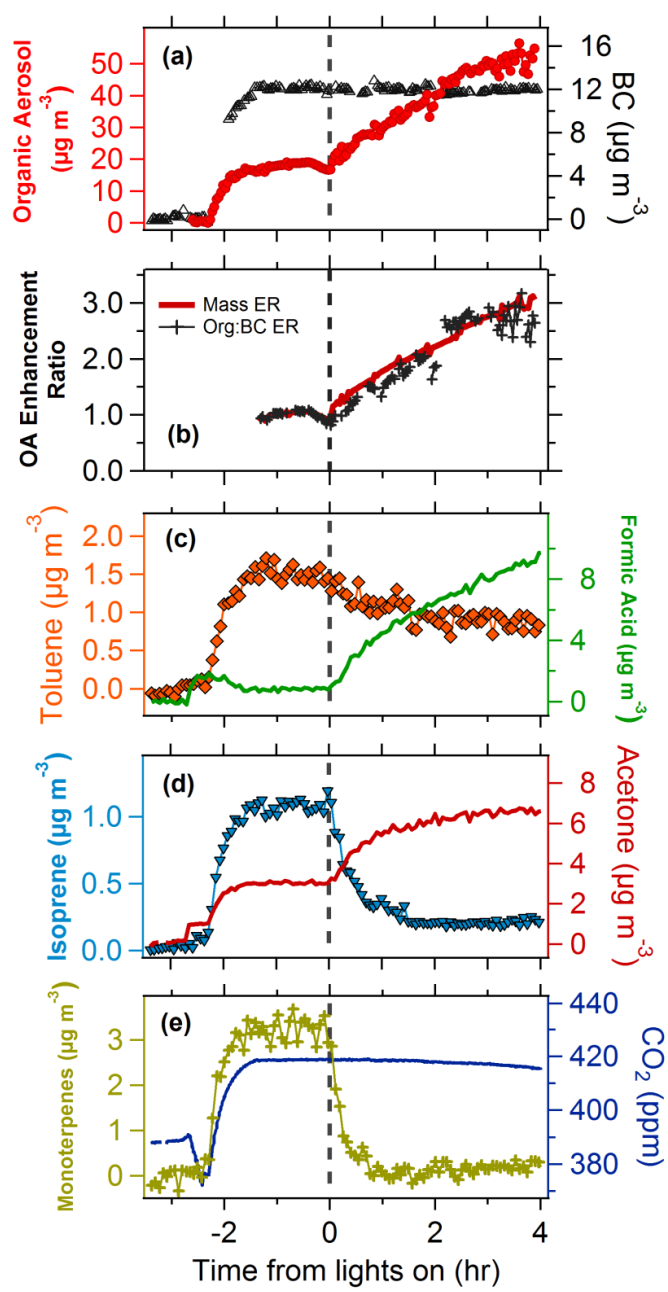

Gallberry (10/6/09):
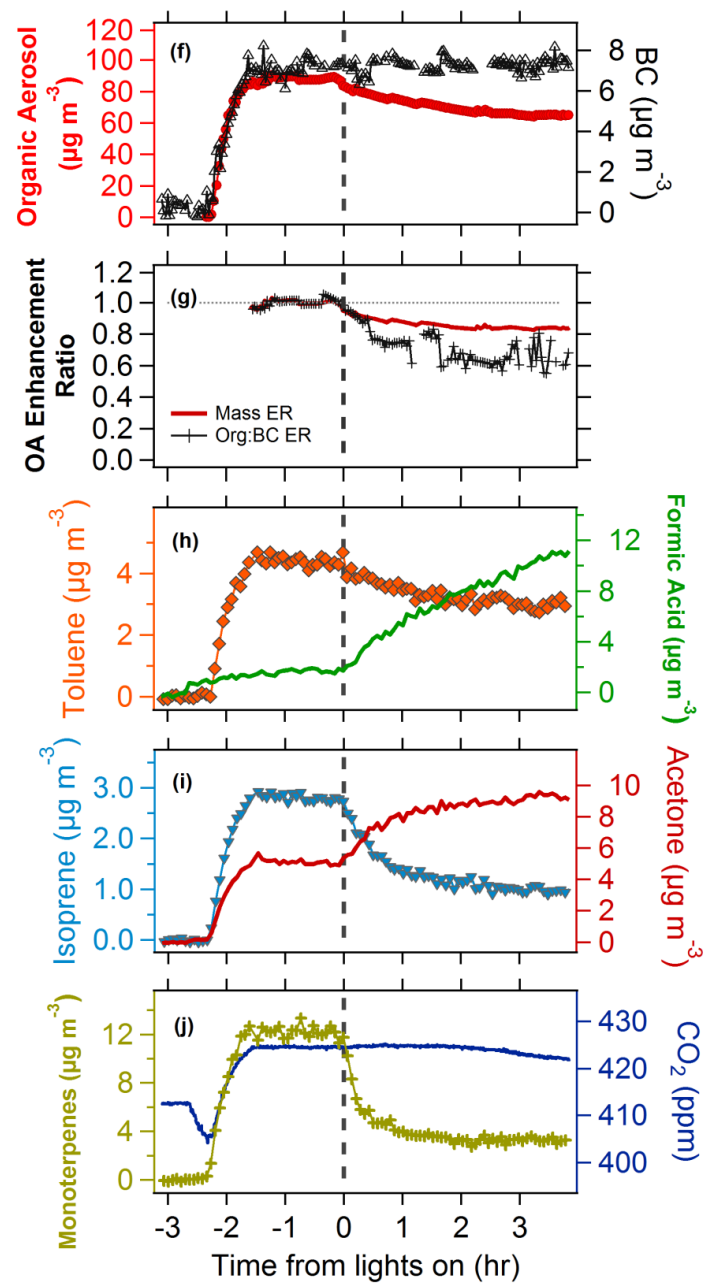

Fig. 2. Measured time series of gas and particle species in experiments where significant OA production was observed (Burn 63, pocosin, panels a-e) and where a net loss of OA mass with aging was observed (Burn 65, gallberry, panels f-j). (a), (f) Wall-loss-corrected OA and BC concentrations. (b), (g) OA mass enhancement ratios calculated using the OA-to-BC ratio and the first-order wall loss rate constant. (c), (h) Toluene and formic acid concentrations measured by the PTR-MS. (d), (i) Isoprene and acetone concentrations measured by the PTR-MS. (e), (j) Monoterpene concentrations estimated using the $\mathrm{m} / z$ 81 signal in the PTR-MS and $\mathrm{CO}_{2}$ levels. Note, isoprene concentrations were likely influenced by furan, which is also detected in the PTR-MS at $\mathrm{m} / \mathrm{z} 69$ (Warneke et al., 2011).

anhydrosugars, including levoglucosan, by IC with pulsed amperometric detection (Sullivan et al., 2011). Primary organic carbon (OC) and elemental carbon (EC) emission factors were determined using Hi-volume filter samples collected in the burn chamber and analyzed by thermal/optical transmission using a Sunset Labs OC/EC analyzer. The Hivolume sampling specifications and OC/EC analysis protocol are as described by Sullivan et al. (2008) and McMeeking et al. (2009). Total hydrocarbon concentrations were also measured in the burn chamber using a Total Hydrocarbon Analyzer (Thermo Environmental, Model 51).

\subsection{Data analysis}

\subsubsection{Emissions data}

Fuel based emission factors were calculated from the measured pollutant concentrations using the carbon mass balance approach (Ward and Radke, 1993):

$\mathrm{EF}_{i}=\frac{m_{i} \cdot x_{\mathrm{C}}}{\Delta \mathrm{CO}_{2}+\Delta \mathrm{CO}+\Delta \mathrm{PM}_{\mathrm{C}}+\Delta \mathrm{HC}}$

where $m_{i}$ is the concentration of species $i, x_{\mathrm{C}}$ is the mass fraction of carbon in the dry fuel determined by chemical analysis, $\triangle \mathrm{CO}_{2}$ is the background-corrected $\mathrm{CO}_{2}$ concentration $\left(\mathrm{g}-\mathrm{C} \mathrm{m}^{-3}\right), \Delta \mathrm{CO}$ is the background-corrected $\mathrm{CO}$ concentration $\left(\mathrm{g}-\mathrm{C} \mathrm{m}^{-3}\right), \Delta \mathrm{PM}_{\mathrm{C}}$ is the background-corrected 


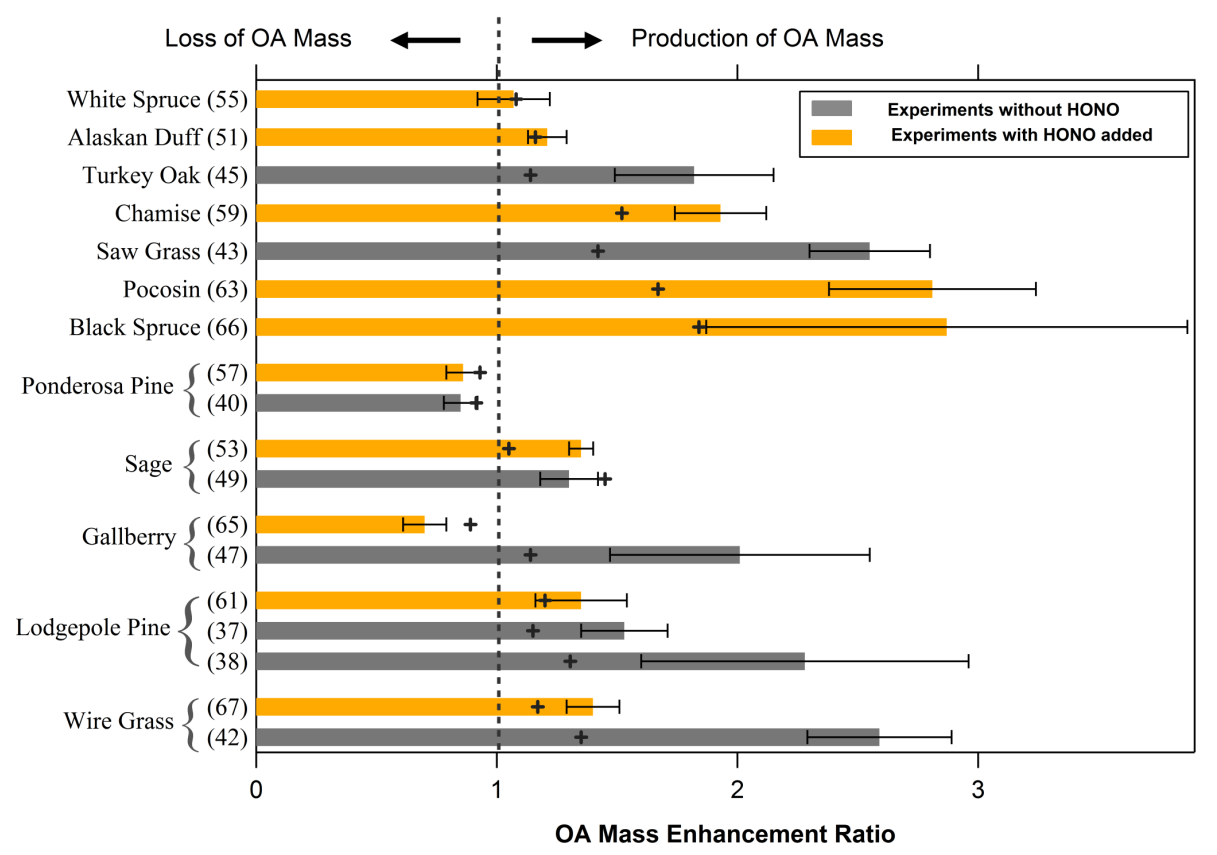

Fig. 3. Organic aerosol mass enhancement ratios measured at the end of the photo-oxidation phase of each experiment (labeled by fuel name, with burn number in parenthesis). Gray color indicates experiments with no HONO addition while orange color indicates experiments where HONO was added to increase $\mathrm{OH}$ levels (see Table 2). Error bars (values given in Table 2) represent measurement uncertainty and differences in OA mass enhancement ratios calculated using the $\mathrm{BC}$ ratio method and direct wall-loss estimate (Sect. 2.2). Black crosses represent OA mass enhancement ratios according to the $\omega=0$ estimate (Sects. 2.2 and 3.2).

carbon in the particle phase $\left(\mathrm{g}-\mathrm{C} \mathrm{m}^{-3}\right)$, and $\Delta \mathrm{HC}$ is the background-corrected carbon concentration of hydrocarbons $\left(\mathrm{g}-\mathrm{C} \mathrm{m}^{-3}\right)$.

The modified combustion efficiency (MCE) was calculated to characterize burn conditions (Ward and Radke, 1993),

$\mathrm{MCE}=\frac{\Delta \mathrm{CO}_{2}}{\Delta \mathrm{CO}_{2}+\Delta \mathrm{CO}}$

where $\Delta \mathrm{CO}_{2}$ and $\triangle \mathrm{CO}$ are the background-corrected $\mathrm{CO}_{2}$ and $\mathrm{CO}$ concentrations $\left(\mathrm{g}-\mathrm{C} \mathrm{m}^{-3}\right)$. During a chamber burn, fuels undergo multiple phases of combustion (see example FLAME II combustion timeline in Lee et al., 2010), thus the emission factors and MCE values reported here are fireintegrated values.

\subsubsection{Chamber data}

To quantify the effects of photochemistry on aerosol mass concentrations, the data must be corrected for loss of particles and vapors to the chamber walls. Wall loss-corrected data were expressed as OA mass enhancement ratios. An OA mass enhancement ratio greater than 1 indicates net production of wall-loss-corrected OA mass (i.e., SOA formation), while an OA enhancement ratio less than 1 indicates net loss of wall-loss-corrected OA mass.
Following Grieshop et al. (2009b), an OA mass enhancement ratio was estimated using the $\mathrm{OA}$ concentration measured by the Q-AMS and the $\mathrm{BC}$ concentration:

$\mathrm{OA}$ mass enhancement ratio $=\frac{\mathrm{OA}_{t} / \mathrm{BC}_{t}}{\mathrm{OA}_{0} / \mathrm{BC}_{0}}$

where $\mathrm{OA}_{t}$ and $\mathrm{BC}_{t}$ are the $\mathrm{OA}$ and $\mathrm{BC}$ concentrations at some time $t$ during the photo-oxidation phase of the experiment, respectively, while $\mathrm{OA}_{0}$ and $\mathrm{BC}_{0}$ are the $\mathrm{OA}$ and $\mathrm{BC}$ concentrations during the primary characterization period. This assumes that the aerosol on the chamber walls remains in equilibrium with semi-volatile vapors $(\omega=1$ case described by Weitkamp et al., 2007).

An alternate estimate used a first order rate loss constant calculated from the measured decay in Q-AMS OA mass during the primary characterization period (before exposing the chamber to UV light). This rate constant was then used to correct for aerosol mass deposited on the chamber following the approach of Weitkamp et al. (2007) assuming that the particles on the walls remained in equilibrium with semi-volatile vapors $(\omega=1$ case described by Weitkamp et al., 2007). The OA mass enhancement ratios reported here are the average of these two estimates (Table 2, Figs. 3 and 8). The lone exception was Burn 51 (Alaskan Duff, 28 September 2009), where BC concentrations were too low to calculate an $\mathrm{OA} / \mathrm{BC}$ ratio. For this experiment, the first-order rate constant approach was the sole method used to calculate the OA 
enhancement ratio. OA enhancement ratios determined using the two methods agreed to within $17 \%$, on average, demonstrating the robust estimates of the particle loss rate to the chamber walls (Fig. 2b and g).

To estimate loss of semi-volatile vapors to the chamber walls, we consider two limiting cases: condensable products only partition to the suspended particles $(\omega=0)$ and material lost to the walls remains completely in equilibrium with the gas phase $(\omega=1)$. The $\omega=1$ assumption serves as an upper bound on the estimate of OA production for each experiment. The lower bound assumption, $\omega=0$ (Weitkamp et al., 2007), assumes only particle mass is lost to the walls (no vapor). The available evidence indicates that the $\omega=1$ case better represents the actual behavior in the chamber (Weitkamp et al., 2007).

To quantify OA volatility, the OA mass fraction remaining (MFR) using the thermodenuder data was defined as:

$\mathrm{MFR}=\frac{\mathrm{OA}_{\mathrm{TD}}}{\mathrm{OA}_{\text {bypass }}}$

where $\mathrm{OA}_{\mathrm{TD}}$ and $\mathrm{OA}_{\text {bypass }}$ are the average $\mathrm{OA}$ concentrations measured downstream of the thermodenuder and bypass line with the Q-AMS, respectively. The TD data were corrected for minor particle losses within the thermodenuder, as determined by differences in the particle number concentration for samples through the thermodenuder compared with particle number concentrations measured in bypass using the SMPS. These losses were less than $10 \%$ for the temperatures used in this study.

\section{Results}

\subsection{Primary emissions}

Table 1 presents burn-average primary emission factors and MCE values for 18 chamber burns. These values were calculated from concentrations measured inside the FSL combustion chamber. We briefly describe these data to provide context for the effects of photo-oxidation and to compare the primary emissions data with published laboratory and field data. Future publications from the FLAME III study will focus on the primary emissions data.

The average $\mathrm{CO}_{2}$ emission factor across all of the burns used for smog chamber experiments was $1737 \pm 110 \mathrm{~g} \mathrm{~kg}^{-1}$ (average $\pm 1 \sigma$ ), which agrees well with laboratory data for the same fuels burned under similar conditions (McMeeking et al., 2009). They are also comparable with emission factors from field studies of open biomass burning (Andreae and Merlet, 2001).

Average $\mathrm{CO}\left(74.9 \pm 24.8 \mathrm{~g} \mathrm{~kg}^{-1}\right.$ (average $\left.\left.\pm 1 \sigma\right)\right)$ and $\mathrm{NO}_{\mathrm{x}}$ $\left(3.5 \pm 1.8 \mathrm{~g} \mathrm{~kg}^{-1}\right.$ (average $\left.\pm 1 \sigma\right)$ ) emission factors were within the range of emission factors reported for previous laboratory-scale burns (e.g., Yokelson et al., 2008; McMeeking et al., 2009; Burling et al., 2010) and field data (Andreae and Merlet, 2001). MCE values in this study ranged from 0.89-0.97 with an average MCE of $0.94 \pm 0.02$ (average $\pm 1 \sigma)$. In general, the MCE values demonstrate the influence from both flaming and smoldering fire conditions.

Emissions of OC were more variable than emissions of EC or any of the gas-phase species discussed above. OC emission factors ranged from $0.4-22.6 \mathrm{~g}-\mathrm{C} \mathrm{kg} \mathrm{kg}^{-1}$ with an average of $8.4 \pm 10.6 \mathrm{~g}_{-} \mathrm{C} \mathrm{kg}^{-1}$ (average $\pm 1 \sigma$ ). EC emission factors ranged from $0.25-1.12 \mathrm{~g} \mathrm{C} \mathrm{kg}^{-1}$, with an average of $0.51 \pm 0.28 \mathrm{~g} \mathrm{C} \mathrm{kg}^{-1}$ (average $\pm 1 \sigma$ ). While variable, the range of OC and EC emission factors are consistent with laboratory (McMeeking et al., 2009) and field data (Andreae and Merlet, 2001). For example, average OC emission factors for the biomass burning classes Savannah and Grasslands, Tropical Forests, Extra Tropical Forests, and Agricultural Residues are 3.4, 5.2, 8.6-9.7, and $3.3 \mathrm{~g} \mathrm{~kg}^{-1}$, respectively (Andreae and Merlet, 2001).

\subsection{Photo-oxidation and SOA production}

To illustrate the effects of photo-oxidation on biomass smoke, Fig. 2 shows the time series data for gas- and particlephase pollutants from two experiments, specifically chosen to represent the different behaviors observed in this study. Figures 2a-e show gas and particle concentrations in the smog chamber during a pocosin experiment (FLAME III Burn 63, 5 October 2009), while Fig. 2f-j show concentrations during a gallberry experiment (Burn 65, 6 October 2009).

Although pollutant concentrations inside the chamber varied from experiment to experiment, depending on emission rates and dilution levels, gas-phase species exhibited similar trends in every experiment. Concentrations of reactive hydrocarbons such as toluene, isoprene, and monoterpenes were stable during the primary characterization period, but decreased significantly with photo-oxidation (dashed vertical line in Fig. 2). Concentrations of oxygenated gas-phase species such as acetone and formic acid increased substantially during the aging period. Inert species such as $\mathrm{CO}_{2}$ remained steady throughout the primary characterization and aging periods in every experiment.

Although gas-phase species behaved similarly in every experiment, there were dramatic differences in the evolution of wall loss-corrected OA concentrations. The two experiments shown in Fig. 2 were chosen to highlight these differences. There was significant SOA formation when the pocosin fire emissions were photo-oxidized (Fig. 2a). At the end of the aging period, the OA mass enhancement ratio in this experiment was 2.8 (Fig. 2b), indicating that SOA formation during the photo-oxidation phase of the experiment almost tripled the wall loss-corrected OA mass. This was one of the experiments with the highest SOA production. However, when the gallberry fire emissions were photo-chemically aged, the wall loss-corrected OA concentration (Fig. 2f) decreased by $30 \%$, despite oxidation of SOA precursors. Therefore, photo-oxidation caused some evaporation of the 
POA. This was the largest measured decrease in wall losscorrected OA mass. Wall loss-corrected concentrations of inert species such as $\mathrm{BC}$ were constant throughout the experiment (Fig. 2a and f).

To illustrate the variability in SOA formation, Fig. 3 compiles the OA mass enhancement ratios measured at the end of the photo-oxidation phase of each experiment. On average, photo-oxidation resulted in significant SOA formation; the campaign-average OA mass enhancement ratio was $1.7 \pm 0.7$ (mean $\pm \sigma$ ). However, as demonstrated in Fig. 2, the observed OA mass enhancement ratios were highly variable, and ranged from significant OA production to a net loss of OA.

The treatment of vapor loss to the chamber walls also impacts OA mass enhancement ratios (Sect. 2.2). The black crosses in Fig. 3 represent the OA mass enhancement ratios assuming no vapor loss to the chamber walls $(\omega=0$ case). Previous experiments indicate that this is unlikely (i.e., Weitkamp et al., 2007; Grieshop et al., 2009b); thus, the values in Table 2 represent our best estimate (i.e., the $\omega=1$ case) of actual OA mass enhancements in these experiments. The $\omega=0$ case serves as a lower bound on the OA mass enhancement. For the entire study, the average OA mass enhancement according to the $\omega=0$ case was $1.2 \pm 0.3$ (mean $\pm \sigma$ ), which is significantly lower than the average of 1.7 calculated using the $\omega=1$ assumption. While we believe that treatment of particle and vapor losses to the walls according to the $\omega=1$ assumption better represents actual smog chamber behavior, the two bounding cases demonstrate the uncertainty that wall losses can have in smog chamber experiments.

Repeat experiments were conducted with several fuels to investigate the effects of photo-oxidation under different VOC: $\mathrm{NO}_{\mathrm{x}}$ conditions. Experiments performed with ponderosa pine (Burns 40 and 57) and sage (Burns 49 and 53) produced similar OA mass enhancements despite differences in VOC: $\mathrm{NO}_{\mathrm{x}}$ ratios. However, experiments with wire grass (Burns 42 and 67) and gallberry (Burns 47 and 65) fire emissions under different VOC: $\mathrm{NO}_{\mathrm{x}}$ conditions produced very different OA mass enhancements (Fig. 3, Table 2). These differences are likely due, in part, to the variability of biomass burning emissions; differences in $\mathrm{VOC}: \mathrm{NO}_{\mathrm{x}}$ ratios (Table 2) may have also contributed to different OA mass enhancements.

Hydroxyl radical $(\mathrm{OH})$ concentrations were inferred using the measured decay of aromatic compounds (see supplemental material of Hennigan et al., 2010). In the pocosin experiment (Burn 63; Fig. 2), the $\mathrm{OH}$ concentration during the first $\sim 30 \mathrm{~min}$ after the lights were turned on was $1.1 \times 10^{7}$ molecules $\mathrm{cm}^{-3}$, and the integrated $\mathrm{OH}$ exposure for the entire aging period was calculated as $8.2 \times$ $10^{10}$ molecules $\mathrm{cm}^{-3} \mathrm{~s}$ (Table 2). In the gallberry experiment (Burn 65; Fig. 2), the initial OH concentration was $5.1 \times 10^{6}$ molecules $\mathrm{cm}^{-3}$, and the integrated $\mathrm{OH}$ exposure was $4.9 \times 10^{10}$ molecules $\mathrm{cm}^{-3} \mathrm{~s}$ (Table 2). These values are representative of typical summertime $\mathrm{OH}$ concentrations and similar to $\mathrm{OH}$ levels that have been observed in fresh biomass burning plumes (Hobbs et al., 2003; Yokelson et al., 2009).

One complication for interpreting the OA enhancement ratios is that the chamber temperature increased by an average of $11.5^{\circ} \mathrm{C}$ during the photo-oxidation period of the experiments. This will shift the equilibrium of semi-volatile organics towards the gas phase (Pankow, 1994), which will, in turn, reduce the OA enhancement ratios. However, we expect this to be, at most, a minor effect. For example, no correlation was observed between OA enhancement ratios and the magnitude of the temperature increase for each experiment (not shown: slope $=0.0, R^{2}=0.0$ ). TD analysis of the aged OA suggests that a temperature increase of $11.5^{\circ} \mathrm{C}$ would cause, on average, only $7 \%$ of the OA to evaporate, which is similar to the temperature sensitivity of $1-2 \%$ of OA per ${ }^{\circ} \mathrm{C}$ observed by previous studies (Grieshop et al., 2009b; Huffman et al., 2009). Thus, it is possible that the temperature increases in the chamber masked modest SOA production. It may also have contributed to the modest evaporation observed in certain experiments.

\subsection{Chemical transformations of $\mathrm{OA}$}

Although the production of new OA mass was highly variable, photo-oxidation chemically and physically transformed the OA in every experiment. In this section, we present multiple pieces of evidence to illustrate these changes, including changes in Q-AMS mass spectra, decreasing levoglucosan concentrations, and decreases in OA volatility with aging. These transformations occurred whether or not there was production of new OA mass, and appeared to be due to both SOA production (condensing organics) and to processing of POA.

\subsubsection{Q-AMS OA MS}

The Q-AMS provides a measure of the chemical composition of the OA. Figures 4, 5, and 6 present a compilation of QAMS data to illustrate the evolution of OA emissions.

Figure 4 plots time series of the coefficient of determination values $\left(R^{2}\right)$ between each measured Q-AMS OA mass spectrum and different reference mass spectra, similar to Grieshop et al. (2009a) and Jimenez et al. (2009). Therefore, each time series shown in Fig. 4 illustrate how the composition of the OA inside the chamber changes relative to a different reference spectrum: the average POA spectrum measured during the primary characterization phase of the experiment, an oxygenated organic aerosol (OOA) factor derived from ambient data collected in Pittsburgh (Zhang et al., 2005), and low-volatility OOA (LV-OOA) and semi-volatile OOA (SV-OOA) factors derived from the Pittsburgh OOA (Ulbrich et al., 2009; Jimenez et al., 2009). Separate time series are shown in Fig. 4 to compare results from low and high OA mass enhancement ratio experiments. One time series 


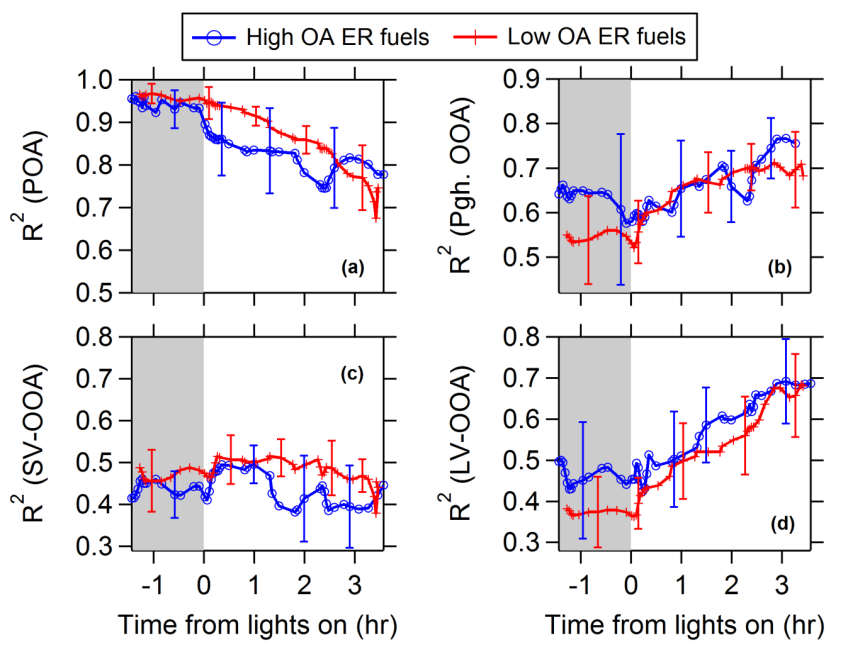

Fig. 4. Evolution of Q-AMS OA mass spectra with photo-oxidation measured during the four experiments with the highest OA mass enhancement ratios (Burns 42, 43, 63, and 66) and during the four experiments with the lowest OA mass enhancement ratios (Burns 40, $55,57$, and 65$)$. The time series show the average coefficient of determination $\left(R^{2}\right)$ values for mass spectra measured at each Q-AMS time step ( $2.5 \mathrm{~min}$ resolution, with thermodenuder data removed) versus different reference spectra: (a) average POA mass spectrum measured before lights on in each experiment, (b) ambient OOA mass spectrum measured in Pittsburgh (Zhang et al., 2005), (c) unitmass-resolution semi-volatile OOA mass spectrum (Ulbrich et al., 2009), and (d) low-volatility OOA spectrum (Ulbrich et al., 2009). Grey shaded regions represent primary characterization period before photo-oxidation was initiated. Select error bars $( \pm 1 \sigma)$ included to show variability in $R^{2}$ values between different experiments.

is the average $R^{2}$ value from the four experiments with the highest OA mass enhancements (Burns 42, 43, 63, and 66; average OA mass enhancement ratio $=2.7$ ) and the second is the average $R^{2}$ value from the four experiments with the lowest OA mass enhancements (Burns 40, 55, 57, and 65; average $\mathrm{OA}$ mass enhancement ratio $=0.9$ ).

In every experiment, photo-oxidation caused the OA mass spectra to become less similar to the POA mass spectrum and more similar to OOA (Zhang et al., 2005). Furthermore, the OA mass spectra in every experiment became more similar to LV-OOA than SV-OOA. Similar trends were reported by Grieshop et al. (2009a), who studied photo-oxidation of residential wood combustion emissions.

Figure 5 presents time series of key mass fragments measured using the Q-AMS: $\mathrm{m} / \mathrm{z} 44$ and $\mathrm{m} / \mathrm{z}$ 60. $\mathrm{m} / \mathrm{z} 44$ (dominated by the $\mathrm{CO}_{2}^{+}$ion, see below) is often used as a measure of the extent of oxygenation while $\mathrm{m} / \mathrm{z}, 60$ (dominated by the $\mathrm{C}_{2} \mathrm{H}_{4} \mathrm{O}_{2}^{+}$ion, see below) is often used as a marker for POA emissions from biomass burning (Alfarra et al., 2007; Lee et al., 2010). These mass fragments are presented as a fraction of total organic aerosol $\left(f_{44}\right.$ and $\left.f_{60}\right)$. Again, separate time series are shown to compare results from high and low OA enhancement ratio experiments.
Figure $5 \mathrm{a}$ and $\mathrm{d}$ shows surprisingly similar evolution of $f_{44}$ in experiments with high and low OA enhancement ratios. For the high OA mass enhancement experiments, the $f_{44}$ increase is expected, since SOA is more oxygenated than the POA. However, the increase in $f_{44}$ in experiments where the OA concentration decreased (Fig. 5d) was unexpected, and indicates significant chemical processing of the POA. Since the wall loss-corrected OA concentration decreased, on average, during these experiments, the addition of oxygen must be offset by the loss of carbon. A similar phenomenon has been observed in plume studies (Capes et al., 2008). These data imply that in some systems fragmentation reactions that break carbon-carbon bonds but add oxygen are important (Kroll et al., 2009).

Figure $5 \mathrm{~b}$ and e shows that photo-oxidation dramatically reduced $f_{60}$. This provides additional evidence for the substantial transformation of POA, especially in experiments with little or no SOA production (low or negative OA mass enhancement ratio). If $\mathrm{m} / \mathrm{z}, 60$ were an inert tracer for biomass burning emissions, then the $f_{60}$ data in Fig. $5 \mathrm{f}$ would lie within the gray shaded region, which is the range of the normalized, wall loss-corrected POA concentrations. Instead, $f_{60}$ decreased rapidly in the first two hours of photooxidation, indicating that reactions depleted the compounds that contributed to the $\mathrm{m} / \mathrm{z}, 60$ signal. This trend was also observed in experiments with substantial SOA formation (Fig. 5b). In these experiments, the rate of $f_{60}$ decrease was much more rapid than the SOA production; therefore the data clearly indicate significant chemical processing of POA even in experiments with substantial SOA production.

Figure 6a presents $f_{44}$ and $f_{43}$ measured at the beginning and end of every experiment using triangle plots, and compares the data to ambient OOA (Ng et al., 2010). Overall, the POA data lies outside of the $f_{44}-f_{43}$ space typically occupied by ambient OOA, due to lower $f_{43}$. After three hours of photo-oxidation, most of the OA moved into the $f_{44}-f_{43}$ space occupied by ambient LV-OOA. This change was driven mostly by an increase in $f_{44}$, as illustrated for a subset of the experiments in Fig. 5. The shift into the $f_{44}-f_{43}$ space with photo-oxidation is also illustrated by the time series in Fig. 4 . The results in Fig. 6a are comparable to those from similar experiments conducted with emissions from wood-burning appliances (Heringa et al., 2011).

Figure $6 \mathrm{~b}$ plots chemical evolution of $f_{44}$ and $f_{60}$ in all experiments performed in this study, with comparisons made to measurements of $\mathrm{OA}$ in aging biomass burning plumes (Cubison et al., 2011). This framework clearly shows that photo-oxidation increased $f_{44}$ and decreased $f_{60}$, consistent with the general evolution of $\mathrm{OA}$ in ambient fire plumes $\mathrm{CCu}-$ bison et al., 2011). The POA measured in these experiments typically have lower $f_{60}$ values than the OA in many ambient biomass burning plumes (Cubison et al., 2011), potentially due, in part, to differences in dilution upon the fresh smoke when sampled into the smog chamber (see Sect. 3.3.2). Overall, Figs. 4-6 demonstrate that the smog chamber OA in these 

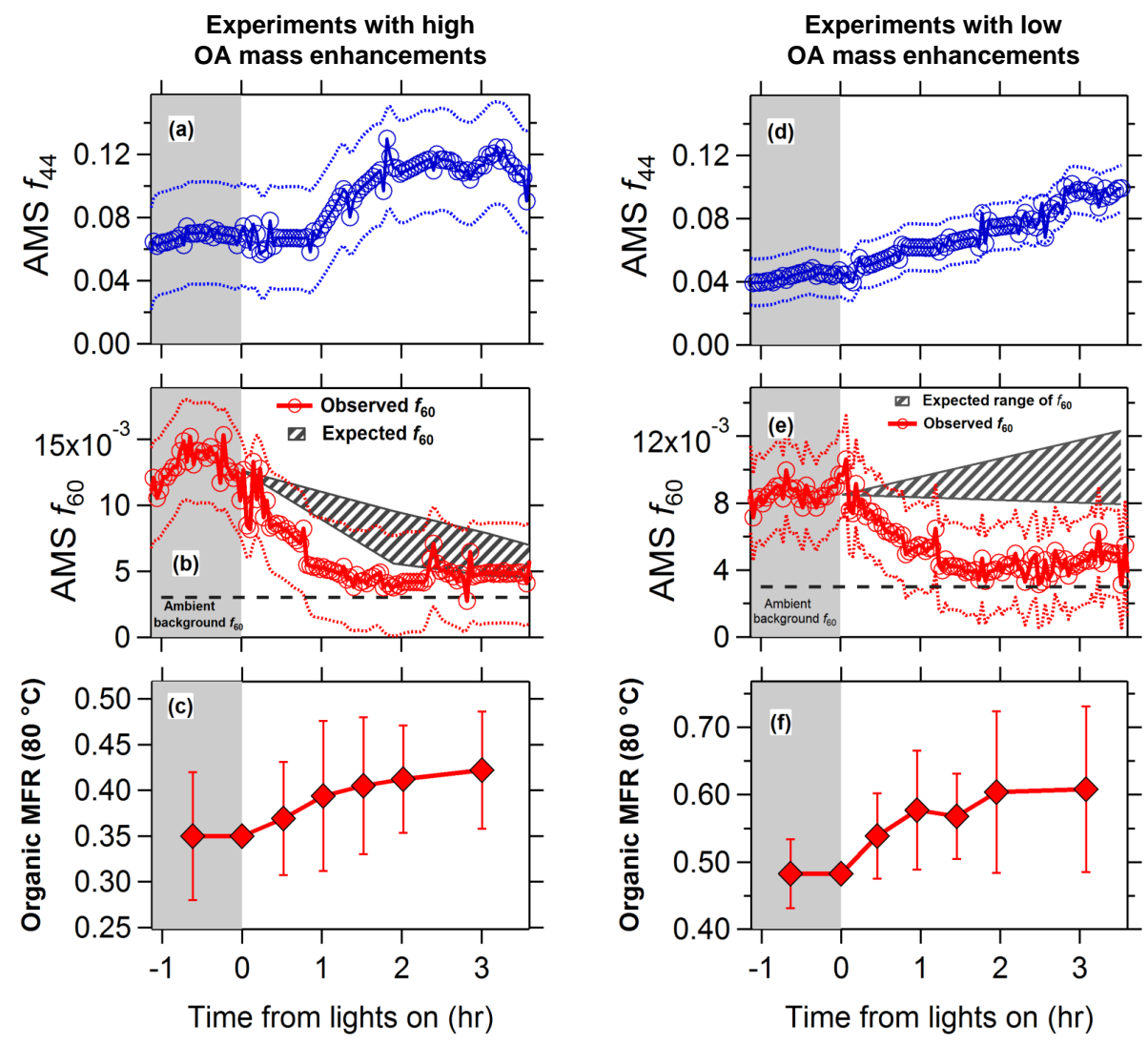

Fig. 5. Changes in chemical and physical properties of organic aerosol for the four experiments with the highest OA mass enhancement ratios (panels a-c: Burns 42, 43, 63, and 66) and the four experiments with the lowest OA mass enhancement ratios (panels d-f: Burns 40, 55, 57, and 65). (a), (d) Changes in the fraction of the total OA mass at $\mathrm{m} / \mathrm{z} 44-f_{44}$. (b), (e) Changes in the fraction of the total OA mass at $m / z 60-f_{60}$. (c), (f) Evolution of OA volatility with time. Error bars and dotted lines represent $\pm 1 \sigma$ from mean.
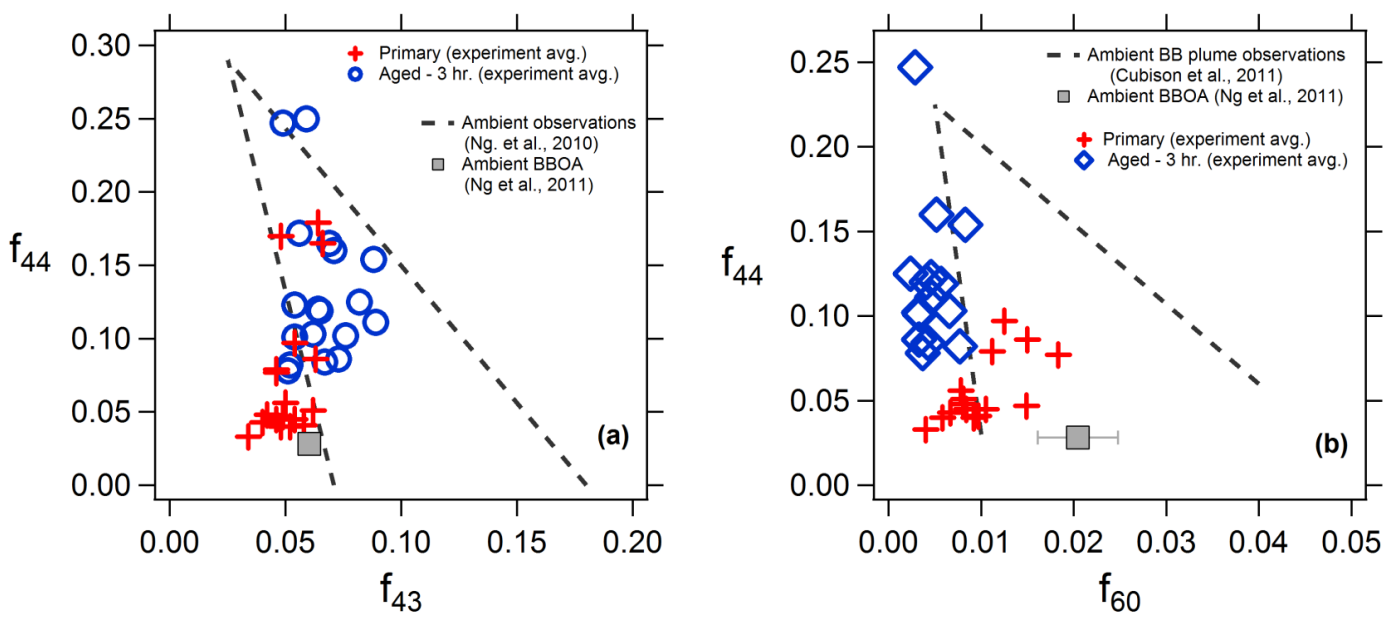

Fig. 6. (a) Comparison of $f_{44}$ and $f_{43}$ and (b) $f_{44}$ and $f_{60}$ measured during the primary characterization period and after $3 \mathrm{~h}$ of photooxidation for each experiment. The data in (a) are compared to $f_{44}$ and $f_{43}$ values from ambient data sets (Ng et al., 2010) and to values from ambient biomass burning organic aerosol (BBOA) spectra derived from factor analysis ( $\mathrm{Ng}$ et al., 2011). The data in (b) are compared to data from ambient biomass burning plumes (Cubison et al., 2011) and to ambient BBOA spectra derived from factor analysis (Ng et al., 2011). Panel (b) does not contain data from Burns 49, 53, and 59 because of low signal-to-noise in $\mathrm{m} / \mathrm{z}, 60$ signal. 


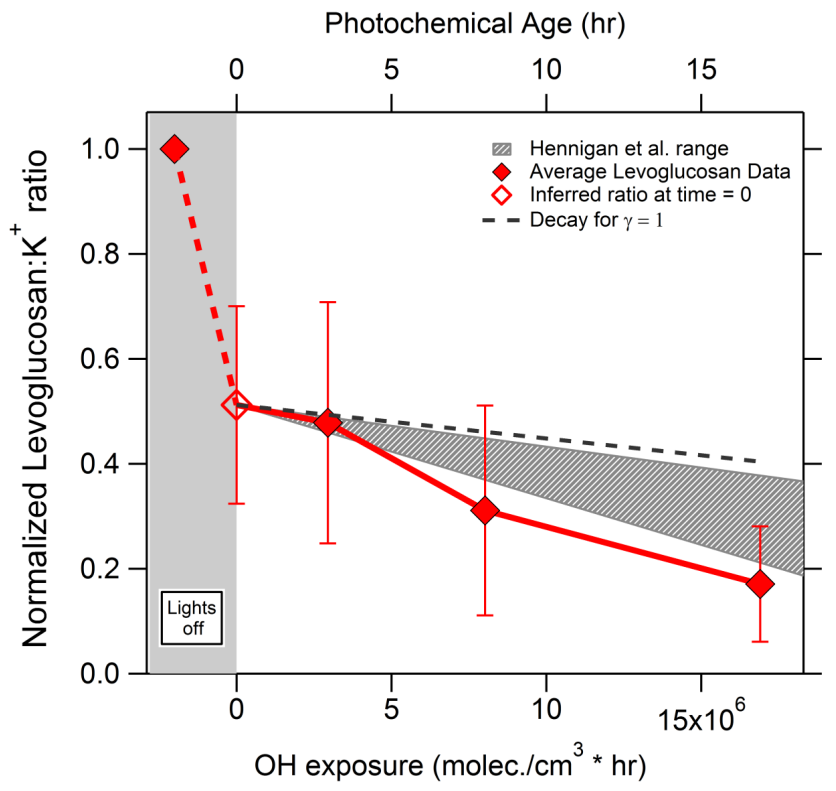

Fig. 7. Evolution of the levoglucosan-to- $\mathrm{K}^{+}$ratio with $\mathrm{OH}$ exposure. Data are normalized by the initial ratio measured in the combustion chamber for each experiment. Solid red symbols represent campaign-average values; the open red symbol is estimated based upon dilution of primary emissions, as described in the text. Error bars represent \pm 1 standard deviation. Photochemical age (top axis) assumes a constant $\mathrm{OH}$ concentration of $1 \times 10^{6}$ molecules $\mathrm{cm}^{-3}$. Solid grey region indicates period prior to photo-oxidation.

experiments underwent similar chemical evolution to OA observed in aging fire plumes and was transformed to resemble LV-OOA that has been observed in many ambient locations.

Fifteen minutes of every hour the HR-AMS sampled from the smog chamber. These measurements confirmed the trends seen in the Q-AMS data (Figs. 4, 5, and 6). The HR-AMS consistently observed an increase in the $\mathrm{CO}_{2}^{+}$to-organic ratio with photo-chemical aging, and a simultaneous decrease in the $\mathrm{C}_{2} \mathrm{H}_{4} \mathrm{O}_{2}^{+}$-to-organic ratio with aging as well, supporting the overall conclusions drawn from the Q-AMS analysis. In addition, the HR-AMS indicates that the dominant ion contributing to the signal at $\mathrm{m} / \mathrm{z} 44$ was $\mathrm{CO}_{2}^{+}$, while the major ion contributing to the signal at $\mathrm{m} / z 60$ was $\mathrm{C}_{2} \mathrm{H}_{4} \mathrm{O}_{2}^{+}$. For example, during Burn 47 (Gallberry, 25 September 2009), $\mathrm{CO}_{2}^{+}$accounted for $89.3 \% \pm 4.5 \%$ (mean $\pm 1 \sigma$ ) of the $\mathrm{m} / \mathrm{z} 44$ signal, and $\mathrm{C}_{2} \mathrm{H}_{4} \mathrm{O}_{2}^{+}$accounted for $98.1 \% \pm 0.8 \%$ (mean $\pm 1 \sigma$ ) of the $m / z 60$ signal during the HR-AMS sampling periods.

\subsubsection{Levoglucosan}

In addition to changes in the AMS mass spectra, photooxidation also reduced the concentration of levoglucosan (1,6-anhydro- $\beta$-D-glucopyranose), which is extensively used as a tracer for biomass burning emissions in source apportionment analysis (Simoneit et al., 1999).
Figure 7 shows campaign-averaged levoglucosan-topotassium ion $\left(\mathrm{K}^{+}\right)$ratios measured using the filter samples as a function of integrated $\mathrm{OH}$ exposure. If levoglucosan and $\mathrm{K}^{+}$are internally mixed and levoglucosan is inert, then this ratio is expected to stay constant. Since this ratio varied widely from burn to burn, the data have been normalized to the initial levoglucosan-to- $\mathrm{K}^{+}$ratio measured in the FSL burn chamber.

Figure 7 shows that the levoglucosan-to- $\mathrm{K}^{+}$ratio decreased dramatically in every experiment. On average, it decreased by $80 \%$ by the end of the photo-oxidation phase of the experiment relative to data measured in the combustion chamber. This decay rate is much more rapid than observed in previous studies (Hennigan et al., 2010; Kessler et al., 2010). A complication in interpreting these data is that initial filter samples were taken in the FSL combustion chamber but the aged samples were taken in the smog chamber. On average, the primary emissions were $\sim 25$ times more dilute inside the smog chamber than inside the combustion chamber. This dilution will cause semi-volatile compounds to evaporate. Therefore we hypothesize that some of the reduction in the levoglucosan-to- $\mathrm{K}^{+}$ratio is due to changes in partitioning caused by dilution; previous studies have also suggested that levoglucosan is semi-volatile (Huffman et al., 2009; Grieshop et al., 2009b; Hennigan et al., 2010). This agrees well with an estimated levoglucosan saturation vapor concentration $\left(\mathrm{C}^{*}\right)$ of $\sim 8 \mu \mathrm{g} \mathrm{m}^{-3}$ at $293 \mathrm{~K}$ calculated using the SIMPOL.1 group contribution method (Pankow and Asher, 2008). It also agrees with an experimentallyderived sub-cooled liquid vapor pressure of levoglucosan of $\sim 12.6 \mu \mathrm{g} \mathrm{m}^{-3}$ at $298 \mathrm{~K}$ (Booth et al., 2011).

We estimated the amount of levoglucosan that evaporated upon dilution in each experiment using HR-AMS $\mathrm{m} / \mathrm{z}$ 60-tosulfate ratios measured inside the FSL combustion chamber and inside the smog chamber. Although multiple compounds contribute to the AMS $m / z 60$ signal, there is a strong correlation between levoglucosan and $\mathrm{m} / \mathrm{z} 60$ (Lee et al., 2010). On average, the $m / z 60$-to-sulfate ratio measured in the smog chamber during the primary characterization period was approximately half that measured in the FSL combustion chamber. Therefore, we estimate that approximately half the measured decrease in levoglucosan-to- $\mathrm{K}^{+}$ratio was due to the $\sim 25 \times$ dilution inside the smog chamber. This approach, while uncertain, should provide a conservative (lower bound) estimate of the amount of levoglucosan that reacted. The open red symbol in Fig. 7 at $\mathrm{OH}$ exposure $=0$ indicates the estimated levoglucosan-to- $\mathrm{K}^{+}$ratio of the primary aerosol inside the smog chamber before photo-oxidation (the solid red symbols are the measured values).

With this correction, Fig. 7 indicates that the levoglucosanto- $\mathrm{K}^{+}$ratio decreased linearly with $\mathrm{OH}$ exposure during the photo-oxidation phase of the experiment. On average, levoglucosan concentrations decreased by approximately $60 \%$ during photo-oxidation after accounting for dilution (relative to open symbol). The effective rate constant $\left(k_{\mathrm{OH}}\right)$ 
for levoglucosan oxidation, averaged across the entire study, was $3.0 \times 10^{-11} \mathrm{~cm}^{3}$ molecule ${ }^{-1} \mathrm{~s}^{-1}$ with a range of 1.0 to $6.3 \times 10^{-11} \mathrm{~cm}^{3}$ molecule ${ }^{-1} \mathrm{~s}^{-1}$. This is within a factor of two of the average levoglucosan oxidation rate reported in a similar laboratory study conducted with residential wood smoke emissions (Hennigan et al., 2010 - hatched grey region in Fig. 7). Both studies highlight variability in levoglucosan oxidation rates, which are likely due to factors such as aerosol matrix effects, and uncertainty in the levoglucosan evaporation estimate applied to the present study. However, the general agreement in levoglucosan oxidation rates between the two studies provides further evidence that levoglucosan is not an inert tracer for biomass burning emissions.

\subsection{Rate of OA chemical transformations}

Our discussion of Figs. 4-7 underscores that rapid chemical processing occurred in every experiment. The $\mathrm{OH}$ concentrations inferred from the decay of aromatics inside the chamber (Table 2) were similar to, or lower than, those observed in aircraft studies of fresh biomass burning plumes (e.g., Hobbs et al., 2003; Yokelson et al., 2009). Therefore, the rate and extent of chemical transformations measured inside the smog chamber are likely to be similar to those that occur in actual fire plumes.

To quantify the processing rate and the potential contribution of heterogeneous reactions to POA transformations, Fig. 7 compares the measured decay of the wall losscorrected levoglucosan concentration to the effective $\mathrm{OH}$ uptake coefficient $\left(\gamma_{\text {eff }}\right)$ calculated using the approach of Sage et al. (2009):

$\gamma_{\mathrm{eff}}=-\frac{2}{3} \frac{\chi_{\text {levo }} \cdot \rho}{\bar{c}} \frac{D_{V}^{3}}{D_{A}^{2}} \frac{\partial \ln C_{\text {levo: }} \mathrm{K}^{+}}{\partial t} \frac{1}{C_{\mathrm{OH}}}$

where $\chi_{\text {levo }}$ is the measured mass fraction of levoglucosan relative to the total OA, $\rho$ is the particle density (assumed to be $\left.1.3 \mathrm{~g} \mathrm{~cm}^{-3}\right), \bar{c}$ is the mean speed of gas-phase $\mathrm{OH}$ molecules, $D_{V}$ is the measured volume-weighted mean particle diameter, $D_{A}$ is the measured surface-area-weighted mean particle diameter, $\frac{\partial \ln C_{\text {levo: } \mathrm{K}^{+}}}{\partial t}$ is the measured decay rate of the levoglucosan-to- $\mathrm{K}^{+}$ratio, and $C_{\mathrm{OH}}$ is the estimated $\mathrm{OH}$ concentration. $\gamma_{\text {eff }}$ is the ratio of the levoglucosan decay rate to the $\mathrm{OH}$ collision rate. Therefore, $\gamma_{\text {eff }}$ represents the fraction of $\mathrm{OH}$ collisions with the particle that result in the reaction of a levoglucosan molecule. It is weighted by the levoglucosan mass fraction of $\mathrm{OA}\left(\chi_{\text {levo }}\right)$ since other condensed-phase compounds also react with $\mathrm{OH}$. Since $\mathrm{OH}$ reactions are likely to occur very near the particle surface, Eq. (5) assumes that any mass transfer limitations within the particle are similar for all constituents of the OA. The analysis is performed using the levoglucosan decay relative to an inert species $\left(\mathrm{K}^{+}\right)$to correct for the effects of wall losses (Sage et al., 2009).

Using average experimental properties (levoglucosan decay, particle size distributions, $\mathrm{OH}$ levels, levoglucosan $\mathrm{OA}$ mass fraction), we calculate a campaign-average $\gamma_{\text {eff }}$ of 5.0, which means the levoglucosan decayed 5 times faster than the $\mathrm{OH}$ collision rate. Therefore, on average, only $20 \%$ of the measured dilution-corrected levoglucosan decrease can be explained by pure heterogeneous reactions. As a point of reference, the $\gamma_{\text {eff }}=1$ line is plotted in Fig. 7; it represents the expected levoglucosan decay based on heterogeneous chemistry.

One possible explanation for the unexpectedly rapid decay of levoglucosan is secondary chemistry, but this is thought to, at most, double the extent of reaction (two reactions with every $\mathrm{OH}$ collision or $\gamma_{\text {eff }}=2$ ) (Hearn and Smith, 2006; Hearn et al., 2007). An alternative explanation is that gas-phase reactions of $\mathrm{OH}$ with semi-volatile vapors contributed to the levoglucosan decrease. This hypothesis is supported by the observations that levoglucosan is semi-volatile (Sect. 3.3.2). The oxidation of semi-volatile vapors will drive further evaporation. This process has been proposed to explain the rapid processing of motor vehicle POA (Lambe et al., 2009; Miracolo et al., 2010). A final possible explanation is that levoglucosan is enhanced on the particle surface relative to other organic species and therefore preferentially oxidized by $\mathrm{OH}$. However, the bottom line is that levoglucosan, and therefore presumably a large fraction of the POA, is rapidly chemically processed - much more rapidly processed than can be explained by heterogeneous uptake of $\mathrm{OH}$.

\subsection{OA volatility evolution}

A final piece of evidence for the dramatic changes in OA properties with photo-oxidation is the changes in volatility. Figure $5 \mathrm{c}$ and $\mathrm{f}$ shows that photo-oxidation decreased the extent of evaporation inside the thermodenuder at $80^{\circ} \mathrm{C}$. This change was observed in both experiments with and without significant SOA formation (Fig. 5c and f). Therefore, the aged aerosol was less volatile than the POA. The largest decreases in OA volatility occurred in the first hour of aging when $\mathrm{OH}$ levels were the highest, while relatively little change in volatility occurred after that, despite continued evolution of the OA chemical composition (Figs. 4-7). Similar changes in volatility were measured during photooxidation of residential wood burning emissions (Grieshop et al., 2009b).

There was also a decrease in experiments with OA mass loss (Fig. 5f). There are several possible explanations for this change. First, oxidation of semi-volatile vapors will lead to evaporation of semi-volatile material from the particle phase to maintain thermodynamic equilibrium (Sect. 3.4), reducing the mass fraction of the most volatile OA components. Second, even in experiments with no net OA mass enhancement there was some SOA formation because the PTR-MS data indicate that some traditional SOA precursors (Fig. 2) were present and were oxidized in these experiments. Third, heterogeneous reactions of POA could also contribute to the 
decrease in OA volatility. It is likely that all of these factors contributed to the observed changes in OA volatility.

\section{Discussion and conclusions}

Photo-oxidation of open biomass burning emissions in an environmental smog chamber produced a wide variability in $\mathrm{OA}$ mass enhancement ratios. The campaign-average OA mass enhancement ratio of 1.7 indicates that, on average, there was significant SOA production in these systems. However, there was significant experiment-to-experiment variability in the SOA production, ranging from a net loss to almost tripling OA mass.

The substantial variability in SOA production reported here is consistent with data from other field and laboratory studies. For example, significant OA production was observed in the aging of residential wood smoke emissions in laboratory studies (Grieshop et al., 2009b; Heringa et al., 2011) and in aircraft measurements of an aging fire plume (Yokelson et al., 2009). However, other aircraft studies report more modest increases in OA concentrations (Reid et al., 1998; DeCarlo et al., 2010) or no increase in OA concentrations at all downwind of fires (Capes et al., 2008; Hecobian et al., 2011; Cubison et al., 2011). There was no correlation between $\mathrm{OH}$ exposure and production of new OA mass, suggesting that other factors were limiting the SOA production: a future manuscript will focus on explaining the variability in OA mass enhancements.

Our results suggest that SOA production from biomass burning could be a significant source of OA globally. Based on primary emissions reported by Bond et al. (2004) the campaign-average OA enhancement factor of 1.7 suggests that the global SOA production from biomass burning is on the order of $20 \mathrm{Tg} \mathrm{yr}^{-1}$ (comparable to primary biomass burning emissions). Our lower-bound campaign-average OA enhancement factor of 1.2 suggests that global SOA production from biomass burning is at least $6 \mathrm{Tg}^{-1}{ }^{-1}$. A complication is that some of this SOA may be embodied in the POA emission factors used by Bond et al. (2004) because of either sampling artifact or gas-particle partitioning biases in the emission measurements (Robinson et al., 2010). Twenty $\mathrm{Tg} \mathrm{yr}^{-1}$ is a factor of 6 to 7 greater than the global POA emissions from all non-biomass burning sources. Better constraining this estimate requires more rigorous analysis using detailed emissions inventories and chemical transport models. Our results suggest that SOA formation from biomass burning emissions likely varies greatly by region according to specific fire and plume aging conditions. However, the scale of global biomass burning emissions and high SOA formation observed from a variety of fuels demonstrate that aging of biomass burning is likely an important component of the global OA burden.

Even though it did not always produce new OA mass, photo-oxidation chemically and physically transformed the biomass burning emissions in every experiment. A unique feature of the smog chamber experiments is our ability to quantify the rate of these transformations. The OA transformations were significantly faster than could be explained by heterogeneous reactions (Fig. 7). In some of the experiments, there was even a net loss of OA mass during photo-oxidation. Molina et al. (2004) proposed that heterogeneous oxidation could be a significant loss mechanism for OA mass. However, the OA mass loss observed in our experiments occurred with much less oxidant exposure than that used in most heterogeneous oxidation experiments (e.g., Molina et al., 2004; Knopf et al., 2006; George et al., 2007; Hearn et al., 2007; Kroll et al., 2009). We hypothesize that oxidation of semivolatile vapors played an important role in the OA mass loss and the chemical processing of the POA.

The extensive transformations of OA blur the traditional definitions of SOA and POA. Traditionally, POA is defined as OA emitted directly into the atmosphere in the particle phase while SOA is comprised of condensable products from reactions of gas-phase organics (Robinson et al., 2010). Most chemical transport models and emission inventories assume that POA is non-volatile and non-reactive.

To illustrate the definitional challenges created by photooxidation, Fig. 8 compares different estimates of POA and SOA from the FLAME III experiments. One approach uses physical definitions to define POA and SOA - POA is the amount of $\mathrm{OA}$ in the chamber before photo-oxidation while SOA is the net production of new OA mass due to photochemistry. The physical definition corresponds to the traditional definition of non-volatile and non-reactive POA. The second approach uses levoglucosan to define the POA concentrations. Levoglucosan is widely used as a tracer for biomass burning POA in receptor models (Simoneit et al., 1999).

We use data from a wire grass experiment (Burn 42) to illustrate the two different definitions for SOA and POA. In this experiment, the OA mass enhancement ratio was $2.6 \pm$ 0.2 after $3.5 \mathrm{~h}$ of aging. Thus, based on the physical definition, the SOA mass fraction of the wall loss-corrected OA at the end of the experiment was $0.6(\mathrm{SOA}=(2.6-1) / 2.6)$ and the POA contribution was 0.4. However, in this experiment, the levoglucosan-to- $\mathrm{K}^{+}$ratio decreased by $64 \%$ between the initial measurement in the FSL combustion chamber and the final aged sample. This indicates that there was significant chemical processing of the POA. Assuming that levoglucosan is a conserved tracer for POA, the mass fraction of unreacted POA at the end of the experiment was only $14 \%$ of the aged OA mass $(\mathrm{POA}=(1-0.64) / 2.6)$. Thus, the actual contribution of unreacted POA to the aged OA mass was much less than if POA is assumed to be inert. We define the difference between the new OA mass and the unreacted POA as aged-POA, which contributed $25 \%$ of the aged OA mass measured at the end of this experiment (aged$\mathrm{POA}=0.64 / 2.6$ ). 


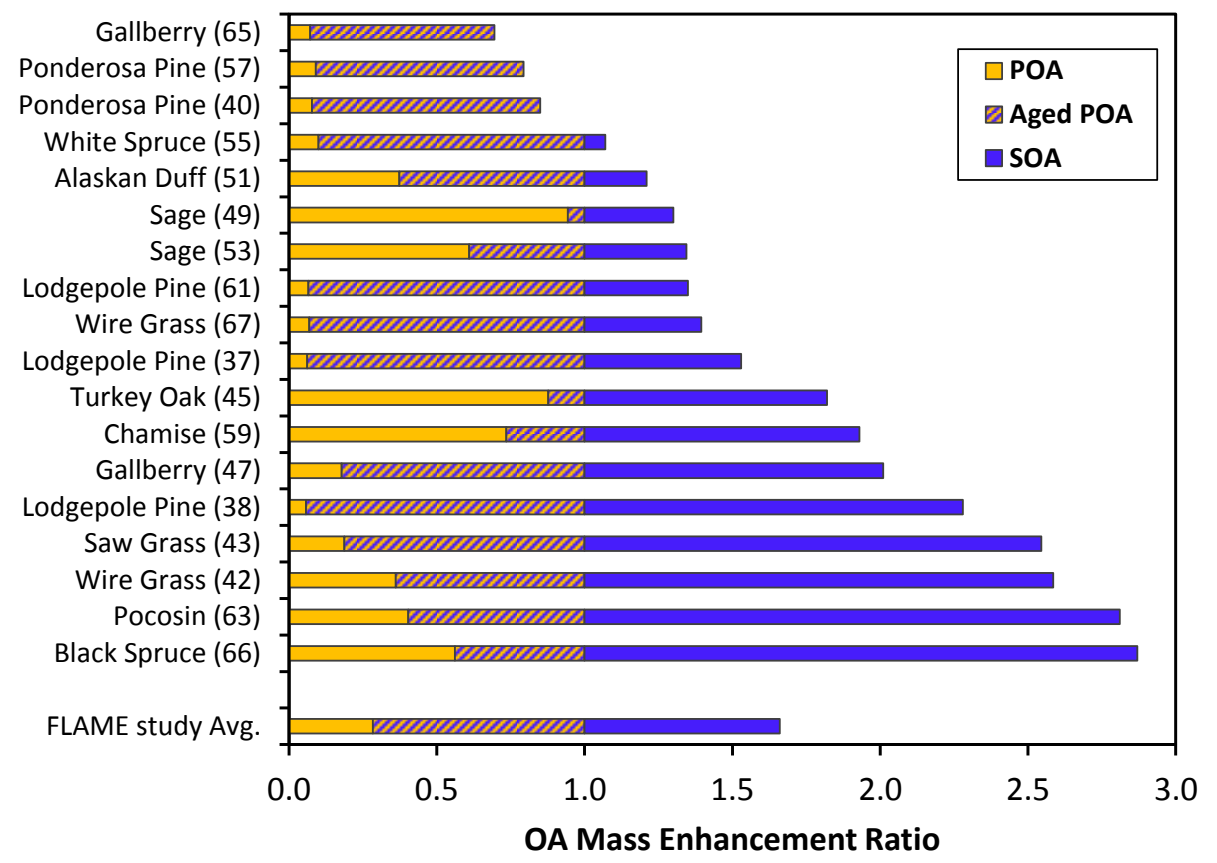

Fig. 8. OA mass enhancement ratios measured at the end of each experiment (burn number in parentheses), as in Fig. 3. Colored portions of each bar indicate the contribution of POA (assuming levoglucosan is an inert tracer), aged-POA and SOA, as described in the text.

Figure 8 plots the end of experiment OA mass enhancement ratios for all burns (the same as Fig. 3) and quantifies the contributions of SOA, POA, and aged-POA mass based on previously discussed definitions. Replacing the traditional definition of POA with one that accounts for oxidation reactions and changes in partitioning dramatically alters our understanding of the contribution of oxidation versus unreacted, direct emissions to OA mass. Assuming a traditional definition (non-volatile and non-reactive POA), POA accounted for $60 \%$ and SOA accounted for $40 \%$ of the campaign-average $\mathrm{OA}$ at the end of the experiment. However, if levoglucosan is assumed to be a conserved tracer for the POA, then POA only accounted for only $17 \%$ of campaign-averaged aged OA while aged-POA accounted for the largest fraction at $43 \%$. This distinction is not precise since some of the aged-POA may be SOA formed from the oxidation of semivolatile vapors that is offset by evaporation of semivolatile POA. The contribution of aged-POA was varied from experiment to experiment; it did no depend on the net change in OA mass. The fractional contribution of agedPOA estimated using levoglucosan qualitatively agrees with the other metrics of chemical transformation of the POA, including Q-AMS analysis (e.g., using $m / z 60$ as a marker for biomass POA, Figs. 4, 5, and 6) and evolution of OA volatility (Fig. 5).

Our definition of aged-POA assumes that all POA reacts at the same rate as levoglucosan. This likely is not true because levoglucosan appears to be semi-volatile (while the other compounds that contribute to POA span a wide range of volatility). Furthermore, the reaction of vapors likely contributed to its depletion in the particle phase. However, receptor models commonly use levoglucosan as an inert tracer for biomass burning POA; therefore, it is a widely applied assumption (Schauer and Cass, 2000). Other laboratory and field studies have reported substantial reaction of levoglucosan (Hoffmann et al., 2010; Hennigan et al., 2010; Kessler et al., 2010; Saarikoski et al., 2008; Zhang et al., 2010; Mochida et al., 2010; Holden et al., 2011). Figure 8 indicates that, on average, using levoglucosan as a tracer for biomass burning emissions could underestimate the contribution of biomass burning to the chamber aerosol by a factor of 7. The use of levoglucosan to estimate biomass burning impacts on ambient aerosol is subject to the largest artifacts in summer, when photo-oxidation is greater and temperatures higher than in winter (Sullivan et al., 2011). This illustrates the dramatic biases created by changing partitioning and reaction of levoglucosan.

The large contribution of aged-POA demonstrates that the physical and chemical transformations of OA were extensive, consistent with results from multiple field studies (e.g., Capes et al., 2008; Mochida et al., 2010; Holden et al., 2011). Our experiments indicate that the OA in biomass burning emissions are rapidly altered (on timescales of hours) at typical atmospheric and plume conditions. Therefore, this dynamic behavior needs to be accounted for in models which are used to evaluate the impact of these emissions on air quality, atmospheric chemistry, and climate. 
Acknowledgements. This work was supported by the National Park Service and Joint Fire Science Program and the EPA STAR program through the National Center for Environmental Research (NCER) under grant R833747. This paper has not been subject to EPA's required peer and policy review, and therefore does not necessarily reflect the views of the Agency. No official endorsement should be inferred.

Edited by: H. Saathoff

\section{References}

Alfarra, M. R., Prevot, A. S. H., Szidat, S., Sandradewi, J., Weimer, S., Lanz, V. A., Schreiber, D., Mohr, M., and Baltensperger, U.: Identification of the mass spectral signature of organic aerosols from wood burning emissions, Environ. Sci. Technol., 41, 57705777, 2007.

Alvarado, M. J. and Prinn, R. G.: Formation of ozone and growth of aerosols in young smoke plumes from biomass burning: 1. Lagrangian parcel studies, J. Geophys. Res.-Atmos., 114, D09306, doi:10.1029/2008JD011144, 2009.

Andreae, M. O. and Merlet, P.: Emission of trace gases and aerosols from biomass burning, Global Biogeochem. Cycles, 15, 955966, 2001.

Bond, T. C., Streets, D. G., Yarber, K. F., Nelson, S. M., Woo, J.H., and Klimont, Z.: A technology-based global inventory of black and organic carbon emissions from combustion, J. Geophys. Res., 109, D14203, doi:10.1029/2003JD003697, 2004

Booth, A. M., Montague, W. J., Barley, M. H., Topping, D. O., McFiggans, G., Garforth, A., and Percival, C. J.: Solid state and subcooled liquid vapour pressures of cyclic aliphatic dicarboxylic acids, Atmos. Chem. Phys., 11, 655-665, doi:10.5194/acp-11655-2011, 2011.

Burling, I. R., Yokelson, R. J., Griffith, D. W. T., Johnson, T. J., Veres, P., Roberts, J. M., Warneke, C., Urbanski, S. P., Reardon, J., Weise, D. R., Hao, W. M., and de Gouw, J.: Laboratory measurements of trace gas emissions from biomass burning of fuel types from the southeastern and southwestern United States, Atmos. Chem. Phys., 10, 11115-11130, doi:10.5194/acp10-11115-2010, 2010.

Capes, G., Johnson, B., McFiggans, G., Williams, P. I., Haywood, J., and Coe, H.: Aging of biomass burning aerosols over West Africa: Aircraft measurements of chemical composition, microphysical properties, and emission ratios, J. Geophys. Res.Atmos., 113, D00C15, doi:10.1029/2008JD009845, 2008.

Christian, T. J., Kleiss, B., Yokelson, R. J., Holzinger, R., Crutzen, P. J., Hao, W. M., Saharjo, B. H., and Ward, D. E.: Comprehensive laboratory measurements of biomassburning emissions: 1. Emissions from Indonesian, African, and other fuels, J. Geophys. Res.-Atmos., 108(D23), 4719, doi:10.1029/2003JD003704, 2003.

Crutzen, P. J. and Andreae, M. O.: Biomass Burning in the Tropics Impact on Atmospheric Chemistry and Biogeochemical Cycles, Science, 250, 1669-1678, 1990.

Cubison, M. J., Ortega, A. M., Hayes, P. L., Farmer, D. K., Day, D., Lechner, M. J., Brune, W. H., Apel, E., Diskin, G. S., Fisher, J. A., Fuelberg, H. E., Hecobian, A., Knapp, D. J., Mikoviny, T., Riemer, D., Sachse, G. W., Sessions, W., Weber, R. J., Weinheimer, A. J., Wisthaler, A., and Jimenez, J. L.: Effects of aging on organic aerosol from open biomass burning smoke in aircraft and lab studies, Atmos. Chem. Phys. Discuss., 11, 12103-12140, doi:10.5194/acpd-11-12103-2011, 2011.

DeCarlo, P. F., Ulbrich, I. M., Crounse, J., de Foy, B., Dunlea, E. J., Aiken, A. C., Knapp, D., Weinheimer, A. J., Campos, T., Wennberg, P. O., and Jimenez, J. L.: Investigation of the sources and processing of organic aerosol over the Central Mexican Plateau from aircraft measurements during MILAGRO, Atmos. Chem. Phys., 10, 5257-5280, doi:10.5194/acp-10-52572010, 2010.

de Gouw, J. and Jimenez, J. L.: Organic Aerosols in the Earth's Atmosphere, Environ. Sci. Technol., 43, 7614-7618, 2009.

de Gouw, J. A., Middlebrook, A. M., Warneke, C., Goldan, P. D., Kuster, W. C., Roberts, J. M., Fehsenfeld, F. C., Worsnop, D. R., Canagaratna, M. R., Pszenny, A. A. P., Keene, W. C., Marchewka, M., Bertman, S. B., and Bates, T. S.: Budget of organic carbon in a polluted atmosphere: Results from the New England Air Quality Study in 2002, J. Geophys. Res.-Atmos., 110, D16305, doi:10.1029/2004JD005623, 2005.

George, I. J., Vlasenko, A., Slowik, J. G., Broekhuizen, K., and Abbatt, J. P. D.: Heterogeneous oxidation of saturated organic aerosols by hydroxyl radicals: uptake kinetics, condensed-phase products, and particle size change, Atmos. Chem. Phys., 7, 4187-4201, doi:10.5194/acp-7-4187-2007, 2007.

Grieshop, A. P., Donahue, N. M., and Robinson, A. L.: Laboratory investigation of photochemical oxidation of organic aerosol from wood fires 2: analysis of aerosol mass spectrometer data, Atmos. Chem. Phys., 9, 2227-2240, doi:10.5194/acp-9-2227-2009, 2009a.

Grieshop, A. P., Logue, J. M., Donahue, N. M., and Robinson, A. L.: Laboratory investigation of photochemical oxidation of organic aerosol from wood fires 1: measurement and simulation of organic aerosol evolution, Atmos. Chem. Phys., 9, 1263-1277, doi:10.5194/acp-9-1263-2009, 2009b.

Hallquist, M., Wenger, J. C., Baltensperger, U., Rudich, Y., Simpson, D., Claeys, M., Dommen, J., Donahue, N. M., George, C., Goldstein, A. H., Hamilton, J. F., Herrmann, H., Hoffmann, T., Iinuma, Y., Jang, M., Jenkin, M. E., Jimenez, J. L., Kiendler-Scharr, A., Maenhaut, W., McFiggans, G., Mentel, Th. F., Monod, A., Prévôt, A. S. H., Seinfeld, J. H., Surratt, J. D., Szmigielski, R., and Wildt, J.: The formation, properties and impact of secondary organic aerosol: current and emerging issues, Atmos. Chem. Phys., 9, 5155-5236, doi:10.5194/acp-95155-2009, 2009.

Heald, C. L., Jacob, D. J., Park, R. J., Russell, L. M., Huebert, B. J., Seinfeld, J. H., Liao, H., and Weber, R. J.: A large organic aerosol source in the free troposphere missing from current models, Geophys. Res. Lett., 32, L18809, doi:10.1029/2005GL023831, 2005.

Hearn, J. D. and Smith, G. D.: A mixed-phase relative rates technique for measuring aerosol reaction kinetics, Geophys. Res. Lett., 33, L17805, doi:10.1029/2006GL026963, 2006.

Hearn, J. D., Renbaum, L. H., Wang, X., and Smith, G. D.: Kinetics and products from reaction of $\mathrm{Cl}$ radicals with dioctyl sebacate (DOS) particles in O2: a model for radical-initiated oxidation of organic aerosols, Phys. Chem. Chem. Phys., 9, 4803-4813, 2007.

Hecobian, A., Liu, Z., Hennigan, C. J., Huey, L. G., Jimenez, J. L., Cubison, M. J., Vay, S., Diskin, G. S., Sachse, G. W., Wisthaler, A., Mikoviny, T., Weinheimer, A. J., Liao, J., Knapp, D. J., 
Wennberg, P. O., Krten, A., Crounse, J. D., Clair, J. St., Wang, Y., and Weber, R. J.: Comparison of the chemical evolution and characteristics of 495 biomass burning plumes intercepted by the NASA DC- 8 aircraft during the ARCTAS/CARB-2008 field campaign, Atmos. Chem. Phys. Discuss., 11, 18589-18631, doi:10.5194/acpd-11-18589-2011, 2011.

Hennigan, C. J., Sullivan, A. P., Collett, J. L., and Robinson, A. L.: Levoglucosan stability in biomass burning particles exposed to hydroxyl radicals, Geophys. Res. Lett., 37, L09806, doi:10.1029/2010GL043088, 2010.

Heringa, M. F., DeCarlo, P. F., Chirico, R., Tritscher, T., Dommen, J., Weingartner, E., Richter, R., Wehrle, G., Prévôt, A. S. H., and Baltensperger, U.: Investigations of primary and secondary particulate matter of different wood combustion appliances with a high-resolution time-of-flight aerosol mass spectrometer, Atmos. Chem. Phys., 11, 5945-5957, doi:10.5194/acp-11-59452011, 2011.

Hobbs, P. V., Sinha, P., Yokelson, R. J., Christian, T. J., Blake, D. R., Gao, S., Kirchstetter, T. W., Novakov, T., and Pilewskie, P.: Evolution of gases and particles from a savanna fire in South Africa, J. Geophys. Res.-Atmosp., 108(D13), 8485, doi:10.1029/2002JD002352, 2003.

Hoffmann, D., Tilgner, A., Iinuma, Y., and Herrmann, H.: Atmospheric Stability of Levoglucosan: A Detailed Laboratory and Modeling Study, Environ. Sci. Technol., 44, 694-699, 2010.

Holden, A. S., Sullivan, A. P., Munchak, L. A., Kreidenweis, S. M., Schichtel, B. A., Malm, W. C., and Collett Jr., J. L.: Determining contributions of biomass burning and other sources to fine particle contemporary carbon in the western United States, Atmos. Environ., 45, 1986-1993, 2011.

Huffman, J. A., Docherty, K. S., Mohr, C., Cubison, M. J., Ulbrich, I. M., Ziemann, P. J., Onasch, T. B., and Jimenez, J. L.: Chemically-Resolved Volatility Measurements of Organic Aerosol from Different Sources, Environ. Sci. Technol., 43, 5351-5357, 2009.

Jimenez, J. L., Canagaratna, M. R., Donahue, N. M., Prevot, A. S. H., et al.: Evolution of Organic Aerosols in the Atmosphere, Science, 326, 1525-1529, 2009.

Kessler, S. H., Smith, J. D., Che, D. L., Worsnop, D. R., Wilson, K. R., and Kroll, J. H.: Chemical Sinks of Organic Aerosol: Kinetics and Products of the Heterogeneous Oxidation of Erythritol and Levoglucosan, Environ. Sci. Technol., 44, 7005-7010, 2010.

Kirchstetter, T. W. and Novakov, T.: Controlled generation of black carbon particles from a diffusion flame and applications in evaluating black carbon measurement methods, Atmos. Environ., 41, 1874-1888, 2007.

Knopf, D. A., Mak, J., Gross, S., and Bertram, A. K.: Does atmospheric processing of saturated hydrocarbon surfaces by NO3 lead to volatilization?, Geophys. Res. Lett., 33, L17816, doi:10.1029/2006GL026884, 2006.

Kroll, J. H., Smith, J. D., Che, D. L., Kessler, S. H., Worsnop, D. R., and Wilson, K. R.: Measurement of fragmentation and functionalization pathways in the heterogeneous oxidation of oxidized organic aerosol, Phys. Chem. Chem. Phys., 11, 8005-8014, 2009.

Lambe, A. T., Miracolo, M. A., Hennigan, C. J., Robinson, A. L., and Donahue, N. M.: Effective Rate Constants and Uptake Coefficients for the Reactions of Organic Molecular Markers (nAlkanes, Hopanes, and Steranes) in Motor Oil and Diesel Primary Organic Aerosols with Hydroxyl Radicals, Environ. Sci.
Technol., 43, 8794-8800, 2009.

Lee, S., Kim, H. K., Yan, B., Cobb, C. E., Hennigan, C., Nichols, S., Chamber, M., Edgerton, E. S., Jansen, J. J., Hu, Y. T., Zheng, M., Weber, R. J., and Russell, A. G.: Diagnosis of aged prescribed burning plumes impacting an urban area, Environ. Sci. Technol., 42, 1438-1444, 2008.

Lee, T., Sullivan, A. P., Mack, L., Jimenez, J. L., Kreidenweis, S. M., Onasch, T. B., Worsnop, D. R., Malm, W., Wold, C. E., Hao, W. M., and Collett, J. L.: Chemical Smoke Marker Emissions During Flaming and Smoldering Phases of Laboratory Open Burning of Wildland Fuels, Aerosol Sci. Technol., 44, I-V, 2010.

McMeeking, G. R., Kreidenweis, S. M., Baker, S., Carrico, C. M., Chow, J. C., Collett, J. L., Hao, W. M., Holden, A. S., Kirchstetter, T. W., Malm, W. C., Moosmuller, H., Sullivan, A. P., and Wold, C. E.: Emissions of trace gases and aerosols during the open combustion of biomass in the laboratory, J. Geophys. Res.Atmos., 114, D19210, doi:10.1029/2009JD011836, 2009.

Miracolo, M. A., Presto, A. A., Lambe, A. T., Hennigan, C. J., Donahue, N. M., Kroll, J. H., Worsnop, D. R., and Robinson, A. L.: Photo-Oxidation of Low-Volatility Organics Found in Motor Vehicle Emissions: Production and Chemical Evolution of Organic Aerosol Mass, Environ. Sci. Technol., 44, 1638-1643, 2010.

Miracolo, M. A., Hennigan, C. J., Ranjan, M., Nguyen, N. T., Gordon, T. D., Lipsky, E. M., Presto, A. A., Donahue, N. M., and Robinson, A. L.: Secondary aerosol formation from photochemical aging of aircraft exhaust in a smog chamber, Atmos. Chem. Phys., 11, 4135-4147, doi:10.5194/acp-11-4135-2011, 2011.

Mochida, M., Kawamura, K., Fu, P. Q., and Takemura, T.: Seasonal variation of levoglucosan in aerosols over the western North Pacific and its assessment as a biomass-burning tracer, Atmos. Environ., 44, 3511-3518, 2010.

Molina, M. J., Ivanov, A. V., Trakhtenberg, S., and Molina, L. T.: Atmospheric evolution of organic aerosol, Geophys. Res. Lett., 31, L22104, doi:10.1029/2004GL020910, 2004.

Ng, N. L., Chhabra, P. S., Chan, A. W. H., Surratt, J. D., Kroll, J. H., Kwan, A. J., McCabe, D. C., Wennberg, P. O., Sorooshian, A., Murphy, S. M., Dalleska, N. F., Flagan, R. C., and Seinfeld, J. H.: Effect of $\mathrm{NO}_{\mathrm{x}}$ level on secondary organic aerosol (SOA) formation from the photooxidation of terpenes, Atmos. Chem. Phys., 7, 5159-5174, doi:10.5194/acp-7-5159-2007, 2007.

Ng, N. L., Canagaratna, M. R., Zhang, Q., Jimenez, J. L., Tian, J., Ulbrich, I. M., Kroll, J. H., Docherty, K. S., Chhabra, P. S., Bahreini, R., Murphy, S. M., Seinfeld, J. H., Hildebrandt, L., Donahue, N. M., DeCarlo, P. F., Lanz, V. A., Prévôt, A. S. H., Dinar, E., Rudich, Y., and Worsnop, D. R.: Organic aerosol components observed in Northern Hemispheric datasets from Aerosol Mass Spectrometry, Atmos. Chem. Phys., 10, 46254641, doi:10.5194/acp-10-4625-2010, 2010.

Ng, N. L., Canagaratna, M. R., Jimenez, J. L., Zhang, Q., Ulbrich, I. M., and Worsnop, D. R.: Real-Time Methods for Estimating Organic Component Mass Concentrations from Aerosol Mass Spectrometer Data, Environ. Sci. Technol., 45, 910-916, 2011.

Pankow, J. F.: An Absorption Model of Gas-Particle Partitioning of Organic Compounds in the Atmosphere, Atmos. Environ., 28, 185-188, 1994.

Pankow, J. F. and Asher, W. E.: SIMPOL.1: a simple group contribution method for predicting vapor pressures and enthalpies of vaporization of multifunctional organic compounds, 
Atmos. Chem. Phys., 8, 2773-2796, doi:10.5194/acp-8-27732008, 2008

Presto, A. A., Nguyen, N. T., Ranjan, M., Reeder, A. J., Lipsky, E. M., Hennigan, C. J., Miracolo, M. A., Riemer, D. D., and Robinson, A. L.: Fine particle and organic vapor emissions from staged tests of an in-use aircraft engine, Atmos. Environ., 45, 3603-3612, 2011.

Reid, J. S., Hobbs, P. V., Ferek, R. J., Blake, D. R., Martins, J. V., Dunlap, M. R., and Liousse, C.: Physical, chemical, and optical properties of regional hazes dominated by smoke in Brazil, J. Geophys. Res., 103(D24), 32059-32080, 1998.

Robinson, A. L., Grieshop, A. P., Donahue, N. M., and Hunt, S. W.: Updating the Conceptual Model for Fine Particle Mass Emissions from Combustion Systems, J. Air Waste Manage. Assoc. 60, 1204-1222, 2010.

Saarikoski, S., Timonen, H., Saarnio, K., Aurela, M., Järvi, L., Keronen, P., Kerminen, V.-M., and Hillamo, R.: Sources of organic carbon in fine particulate matter in northern European urban air, Atmos. Chem. Phys., 8, 6281-6295, doi:10.5194/acp-86281-2008, 2008.

Sage, A. M., Weitkamp, E. A., Robinson, A. L., and Donahue, N. M.: Reactivity of oleic acid in organic particles: changes in oxidant uptake and reaction stoichiometry with particle oxidation, Phys. Chem. Chem. Phys., 11, 7951-7962, 2009.

Schauer, J. J. and Cass, G. R.: Source Apportionment of Wintertime Gas-Phase and Particle-Phase Air Pollutants Using Organic Compounds as Tracers, Environ. Sci. Technol., 34, 1821-1832, 2000

Simoneit, B. R. T., Schauer, J. J., Nolte, C. G., Oros, D. R., Elias, V. O., Fraser, M. P., Rogge, W. F., and Cass, G. R.: Levoglucosan, a tracer for cellulose in biomass burning and atmospheric particles, Atmos. Environ., 33, 173-182, 1999.

Sullivan, A. P., Holden, A. S., Patterson, L. A., McMeeking, G. R., Kreidenweis, S. M., Malm, W. C., Hao, W. M., Wold, C. E., and Collett, J. L.: A method for smoke marker measurements and its potential application for determining the contribution of biomass burning from wildfires and prescribed fires to ambient PM2.5 organic carbon, J. Geophys. Res.-Atmos., 113, D22302, doi:10.1029/2008JD010216, 2008.

Sullivan, A. P., Frank, N., Onstad, G., Simpson, C. D., and Collett Jr., J. L.: Application of High-Performance Anion-Exchange Chromatography - Pulsed Amperometric Detection for Measuring Carbohydrates in Routine Daily Filter Samples Collected by a National Network: 1. Determination of the Impact of Biomass Burning in the Upper Midwest, J. Geophys. Res., 116, D08302, doi:10.1029/2010JD014166, 2011.
Ulbrich, I. M., Canagaratna, M. R., Zhang, Q., Worsnop, D. R., and Jimenez, J. L.: Interpretation of organic components from Positive Matrix Factorization of aerosol mass spectrometric data, Atmos. Chem. Phys., 9, 2891-2918, doi:10.5194/acp-9-2891-2009, 2009.

Ward, D. E. and Radke, L. F.: Emission measurements from vegetation fires: A comparative evaluation of methods and results, in: Fire in the Environment: The Ecological, Atmospheric, and Climatic Importance of Vegetation Fires, edited by: Crutzen, P. J. and Goldammer, J. G., John Wiley, New York, 53-76, 1993.

Warneke, C., Roberts, J. M., Veres, P., Gilman, J., Kuster, W. C., Burling, I., Yokelson, R., and de Gouw, J. A.: VOC identification and inter-comparison from laboratory biomass burning using PTR-MS and PIT-MS, Int. J. Mass Spectr., 303(1), 6-14, doi:10.1016/j.ijms.2010.12.002, 2011.

Weitkamp, E. A., Sage, A. M., Pierce, J. R., Donahue, N. M., and Robinson, A. L.: Organic aerosol formation from photochemical oxidation of diesel exhaust in a smog chamber, Environ. Sci. Technol., 41, 6969-6975, 2007.

Yokelson, R. J., Griffith, D. W. T., and Ward, D. E.: Openpath Fourier transform infrared studies of large-scale laboratory biomass fires, J. Geophys. Res.-Atmos., 101, 21067-21080, doi:10.1029/96JD01800, 1996.

Yokelson, R. J., Christian, T. J., Karl, T. G., and Guenther, A. The tropical forest and fire emissions experiment: laboratory fire measurements and synthesis of campaign data, Atmos. Chem. Phys., 8, 3509-3527, doi:10.5194/acp-8-3509-2008, 2008.

Yokelson, R. J., Crounse, J. D., DeCarlo, P. F., Karl, T., Urbanski, S., Atlas, E., Campos, T., Shinozuka, Y., Kapustin, V., Clarke, A. D., Weinheimer, A., Knapp, D. J., Montzka, D. D., Holloway, J., Weibring, P., Flocke, F., Zheng, W., Toohey, D., Wennberg, P. O., Wiedinmyer, C., Mauldin, L., Fried, A., Richter, D., Walega, J., Jimenez, J. L., Adachi, K., Buseck, P. R., Hall, S. R., and Shetter, R.: Emissions from biomass burning in the Yucatan, Atmos. Chem. Phys., 9, 5785-5812, doi:10.5194/acp-9-5785-2009, 2009.

Zhang, Q., Alfarra, M. R., Worsnop, D. R., Allan, J. D., Coe, H., Canagaratna, M. R., and Jimenez, J. L.: Deconvolution and quantification of hydrocarbon-like and oxygenated organic aerosols based on aerosol mass spectrometry, Environ. Sci. Technol., 39, 4938-4952, 2005.

Zhang, X., Hecobian, A., Zheng, M., Frank, N. H., and Weber, R. J.: Biomass burning impact on $\mathrm{PM}_{2.5}$ over the southeastern US during 2007: integrating chemically speciated FRM filter measurements, MODIS fire counts and PMF analysis, Atmos. Chem. Phys., 10, 6839-6853, doi:10.5194/acp-10-6839-2010, 2010. 